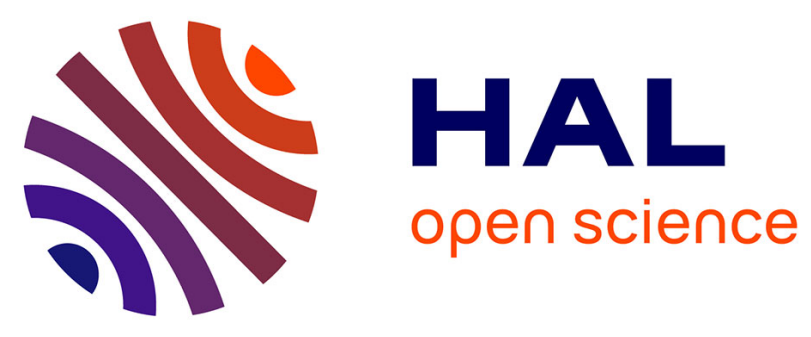

\title{
Discovery of Isoerianin Analogues as Promising Anticancer Agents
}

Samir Messaoudi, Abdallah Hamze, Olivier Provot, Bret Tréguier, Jordi

Rodrigo de losada, Jérôme Bignon, Jian-Miao Liu, Joanna Wdzieczak-Bakala, Sylviane Thoret, Joëlle Dubois, et al.

\section{To cite this version:}

Samir Messaoudi, Abdallah Hamze, Olivier Provot, Bret Tréguier, Jordi Rodrigo de losada, et al.. Discovery of Isoerianin Analogues as Promising Anticancer Agents. ChemMedChem, 2011, 6 (3), pp.488-497. 10.1002/cmdc.201000456 . hal-02394454

\section{HAL Id: hal-02394454 https://hal.science/hal-02394454}

Submitted on 4 Dec 2019

HAL is a multi-disciplinary open access archive for the deposit and dissemination of scientific research documents, whether they are published or not. The documents may come from teaching and research institutions in France or abroad, or from public or private research centers.
L'archive ouverte pluridisciplinaire HAL, est destinée au dépôt et à la diffusion de documents scientifiques de niveau recherche, publiés ou non, émanant des établissements d'enseignement et de recherche français ou étrangers, des laboratoires publics ou privés. 


\title{
Discovery of Isoerianin Analogues as Promising Anticancer Agents
}

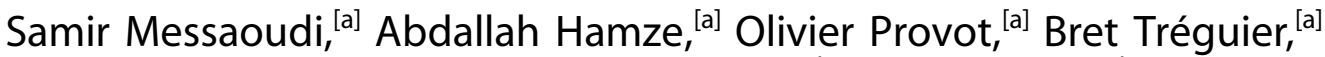 \\ Jordi Rodrigo De Losada, ${ }^{[a]}$ Jérôme Bignon, ${ }^{[b]}$ Jian-Miao Liu, ${ }^{[b]}$ Joanna Wdzieczak-Bakala, ${ }^{[b]}$ \\ Sylviane Thoret, ${ }^{[b]}$ Joëlle Dubois, ${ }^{[b]}$ Jean-Daniel Brion, ${ }^{[a]}$ and Mouad Alami* ${ }^{[a]}$
}

\begin{abstract}
The cytotoxic activity of a series of 23 new isoerianin derivatives with modifications on both the $A$ and $B$ rings was studied. Several compounds exhibited excellent antiproliferative activity at nanomolar concentrations against a panel of human cancer cell lines. The most cytotoxic compound, isoerianin (3), strongly inhibits tubulin polymerization in the micromolar range. Moreover, isoerianin leads to $\mathrm{G}_{2} / \mathrm{M}$ phase cell-cycle arrest in $\mathrm{H} 1299$ and $\mathrm{K} 562$ cancer cells, and strongly induces apoptosis. Isoerianin also disrupts the vessel-like structures
\end{abstract}

formed by human umbilical vein endothelial cells (HUVECs) in vitro, suggesting that this compound may act as a vascular disrupting agent. It clearly appears that in this compound series, the 1,1-ethane bridge encountered in isoerianin derivatives can replace the 1,2-ethane bridge of natural erianin with no loss of activity. This reinforces the bioisosteric replacement approach in the combretastatin series previously reported by our research group.

\section{Introduction}

Combretastatin A-4 (CA-4, 1 a; Figure 1) is a natural cis-stilbene that was isolated by Pettit et al. in 1989 from the South African willow tree Combretum caffrum. ${ }^{[1]}$ Because of its structural sim-
The corresponding water-soluble disodium phosphate prodrug $\left(C A-4 \mathrm{P}^{[4,5]} \mathbf{1} \mathrm{b}\right)$ and the amino derivative (AVE-8062, ${ }^{[3]}$ 1 c) are the preferred leads for human studies. They have been demonstrated to cause vascular shutdown in established tumors in vivo, consistent with an antivascular mechanism of action. CA-4P, either as a single agent or in combination therapy, is currently undergoing several advanced clinical trials worldwide for the treatment of age-related macular degeneration $(A M D)^{[6]}$ and anaplastic thyroid cancer. ${ }^{[7]}$ Despite the remarkable anticancer activity of these stilbenes, the $Z$-configured double bond is prone to isomerization to the more thermally stable $E$ isomer during storage and administration, resulting in a dramatic loss of cytotoxicity. ${ }^{[8]}$ plicity and strong anticancer properties, CA-4 is presently one of the most promising and more heavily studied compounds. CA-4 has been found to be a potent inhibitor of tubulin polymerization, as it binds to the colchicine binding site and exerts significant cytotoxicity toward a wide range of human cancer cell lines, including multidrug-resistant cancer cells. ${ }^{[2]}$ However, its poor pharmacokinetics profile, resulting from its high lipophilicity and low aqueous solubility, limits its efficacy in vivo. ${ }^{[3]}$ [a] Dr. S. Messaoudi, Dr. A. Hamze, Dr. O. Provot, B. Tréguier, Dr. J. Rodrigo De Losada, Prof. J.-D. Brion, Dr. M. Alami Université Paris-Sud, CNRS, BioCIS-UMR 8076

Laboratoire de Chimie Thérapeutique, Faculté de Pharmacie

5 Rue J.-B. Clément, Châtenay-Malabry, 92296 (France)

Fax: $(+33)$ 1.46.83.58.28

E-mail:mouad.alami@u-psud.fr

[b] Dr. J. Bignon, Dr. J.-M. Liu, Dr. J. Wdzieczak-Bakala, S. Thoret, Dr. J. Dubois Institut de Chimie des Substances Naturelles, UPR 2301, CNRS Avenue de la Terrasse, 91198 Gif-sur-Yvette (France) 
As a part of our search for novel tubulin polymerization inhibitors, ${ }^{[9,10]}$ we recently synthesized and evaluated the biological properties of a new series of 1,1-diarylethylene derivatives with general structure 2 (Figure 1). ${ }^{[11]}$ We demonstrated that bioisosteric replacement of the (Z)-1,2-ethylene portion with a 1,1-ethylene bridge resulted in retention of biological activities. $^{[12]}$ Three representative compounds, isoCA-4 (2a), iso$\mathrm{NH}_{2} \mathrm{CA}-4$ (2 b), and isoFCA-4 (2 c) emerged as lead compounds. They display antiproliferative activity with $\mathrm{Gl}_{50}$ values ranging from 2 to $10 \mathrm{~nm}$ against various human cancer cell lines. Flow cytometric analysis indicated that these drugs act as antimitotic substances and arrest the cell cycle in the $G_{2} / M$ phase. ${ }^{[11]}$ Moreover, 1,1-diarylethylenes ${ }^{[13]}$ of type 2 are stable (no isomerization) and easy to synthesize ${ }^{[14]}$ without the need to control the (Z)-olefin geometry.

On the basis of these bioisosteric considerations, we hypothesized that compounds of type 3 bearing a 1,1-diarylethane scaffold could be as active as the natural isomer erianin, which displays important anticancer activities. ${ }^{[15]}$ Moreover, compounds $\mathbf{3}$ could be regarded as simplified analogues of podophyllotoxin, ${ }^{[16]}$ a highly potent cytotoxic and antimitotic substance. We evaluated the biological effects of reducing the 1,1-diarylethylene double bond on biological activity through a small library of novel reduced isoCA-4 analogues. Preliminary evaluation of these compounds in terms of their cytotoxicity toward various human cancer cell lines, inhibition of tubulin assembly, cell cycle, and apoptosis were studied. The interesting biological results obtained with compound $\mathbf{3} \mathbf{a}$ (isoerianin)-high cytotoxicity and potent inhibition of tubulin assembly-further validated the bioisosteric replacements in which a 1,1-ethane moiety mimics a 1,2-ethane bridge.

\section{Results and Discussion}

\section{Chemistry}

Isoerianin derivatives $\mathbf{3} \mathbf{a}$ and 5-26 were prepared by reduction of 1,1-diarylethylenes $2^{[11]}$ readily obtained via palladium-catalyzed reactions of $\mathrm{N}$-tosylhydrazones with various aryl halides $^{[14,17]}$ (Scheme 1). The water-soluble phosphate prodrug 4 was obtained from isoCA-4 by dibenzyl phosphate phosphory- lation of the phenolic function followed by hydrogenolysis and the concomitant reduction sequence $\left(\mathrm{H}_{2}, \mathrm{Pd} / \mathrm{C}\right.$ in EtOAc). The preparation of compounds $\mathbf{2 7}$ and $\mathbf{2 8}$ involved a reaction sequence in three steps: Wittig olefination of phenstatin silyl ether, ${ }^{[18]}$ cleavage of the $\mathrm{O}-\mathrm{Si}$ bond with tetra- $n$-butylammonium fluoride (TBAF) and finally reduction of the $\mathrm{C}=\mathrm{C}$ double bond.

\section{Biological evaluation}

\section{In vitro cell growth inhibition}

All the synthesized compounds were tested in a preliminary cytotoxic assay with the HCT-116 human colon carcinoma cell line, using CA-4, isoCA-4, and erianin as reference compounds. The results are reported in Table 1.

Several isoerianin analogues retained potent growth inhibitory activity at nanomolar concentrations against cancer cells. In particular, the best results were observed with compounds $\mathbf{3}$ a (isoerianin), 14, 15, 17, 27, and 28. Interestingly, both enantiomers of $\mathbf{3} \mathbf{a}$, obtained after separation by chiral HPLC, showed similar antiproliferative potencies against HCT-116 cells $\left[G l_{50}\right.$ values: (+)-3, $26 \mathrm{~nm}$; (-)-3, $29 \mathrm{~nm}$. The water-soluble phosphate derivative 4 retained the activity shown by the parent molecule $\mathbf{3}$ a $\left(\mathrm{GI}_{50}=100 \mathrm{~nm}\right)$.

The 3,4,5-trimethoxyphenyl group appears to be essential. Seemingly minor changes, such as replacing the 3,4,5-trimethoxyphenyl (compound 17) with 3,5-dimethoxyphenyl (compound 21) or 3-ethoxy-4-methoxyphenyl (compound 22), caused an approximate 5- to 100-fold decrease in cytotoxicity. Variations of the $B$ ring of isoerianin derivatives had a significant impact on cytotoxicity. Introduction of 3-fluoro-4-methoxyphenyl, 3-amino-4-methoxyphenyl, or 6-N-methylindole substituents as the $B$ ring (see 5,17 , and $\mathbf{1 5}$, respectively) provided the most promising cytotoxic agents of this series. Moreover, compounds $\mathbf{2 7}$ and $\mathbf{2 8}$, with $\mathrm{CH}_{2} \mathrm{CN}$ or $\mathrm{CF}_{2}$ groups at the benzylic position, respectively, showed cytotoxic activities similar to that of $\mathbf{3} \mathbf{a}$, suggesting that small substituents at the benzylic position are favorable for cytotoxicity. In contrast, diarylmethane compound 29, bearing no substituent at the benzylic position, is not active against HCT-116 cells. From these considerations, it appears that reduction of the double bond of isoCA-4 derivatives, leading to substituted benzylic drugs, is well tolerated for cytotoxicity, and some variations at the $B$ ring are also permitted.<smiles>[R]c1cc(C(=O)c2ccc(OC)c(OCC)c2)cc([R])c1OC</smiles><smiles>[R]c1cc(C(c2ccc(OC)c(O)c2)C(F)F)cc([R])c1OC</smiles>

Scheme 1. Synthesis of isoerianin analogues 3-28: a) Pd(OAc) $2_{2}(5 \mathrm{~mol} \%)$, XPhos (10 mol \%), tBuOLi (2 equiv), dioxane, $90^{\circ} \mathrm{C}, 3-4 \mathrm{~h}$; b) $\mathrm{H}_{2}, \mathrm{Pd} / \mathrm{C}, \mathrm{EtOAC}, 20^{\circ} \mathrm{C}$, overnight; c) 1. (EtO) ${ }_{2} \mathrm{POCH}_{2} \mathrm{CN}$, LiHMDS, 2. TBAF, THF, 3. $\mathrm{H}_{2}, \mathrm{Pd} / \mathrm{C}$, EtOAc, $20^{\circ} \mathrm{C}$, overnight; d) 1. (EtO) ${ }_{2} \mathrm{POCHF}_{2}$, LiHMDS, 2. TBAF, THF, 3. $\mathrm{H}_{2}, \mathrm{Pd} / \mathrm{C}, \mathrm{EtOAC}, 20^{\circ} \mathrm{C}$, overnight.

\section{Cytotoxicity and inhibition of tubulin polymerization for selected compounds}

To characterize the cytotoxicity profiles of these compounds, we investigated the effect of the more active substances $3 \mathrm{a}, \mathbf{1 5}$, 


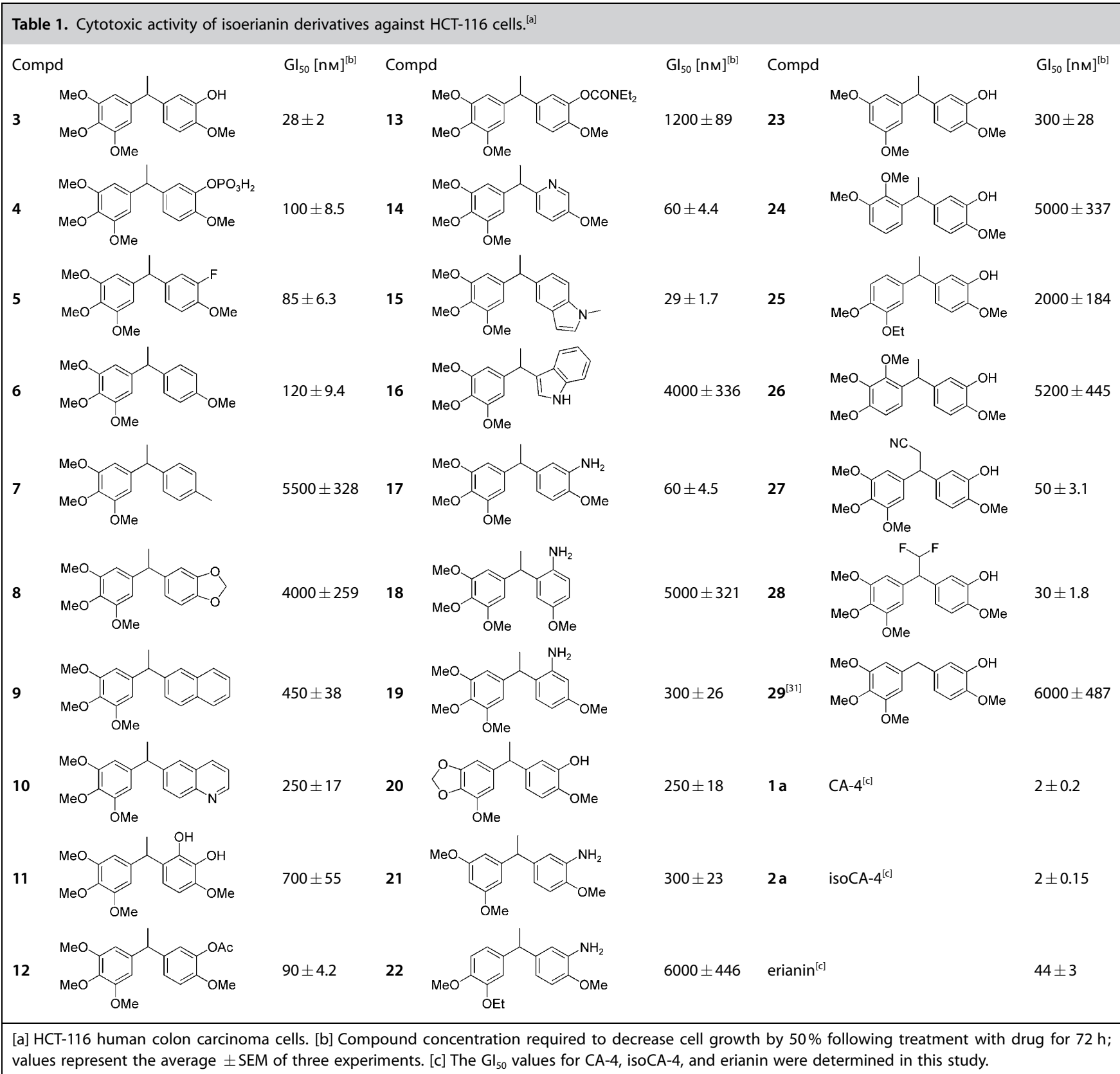

17,27 , and $28\left(\mathrm{Gl}_{50}<60 \mathrm{~nm}\right)$ as well as the water-soluble prodrug 4 on the proliferation of four tumor cell lines [myelogenous leukemia (K562), non-small-cell lung carcinoma (H1299), human breast cancer (MDA-MB435), and hormone-independent breast cancer (MDA-MB231)] as well as normal primary human umbilical vein endothelial cells (HUVEC).

The screening results revealed that the selected compounds strongly inhibit the growth of all examined tumor cell lines, and this effect does not depend on the cell type (Table 2). Again, isoCA-4 and CA-4 themselves were slightly more cytotoxic than any other compound toward the same cancer cell lines, but the $\mathrm{GI}_{50}$ values of selected derivatives did not differ from that observed for isoerianin. Therefore, for antiproliferative activities the 1,1-ethane bridge appears to be a suitable re- placement for the 1,2-ethane group in this series. To investigate whether these compounds exert their activities by interacting with microtubules, their effects on the in vitro polymerization of tubulin were examined. Tubulin was purified from porcine brain tissue according to a slight modification of the protocol reported by Guénard and colleagues. ${ }^{[19]}$ All selected compounds inhibited tubulin polymerization with $\mathrm{IC}_{50}$ values from 3 to $30 \mu \mathrm{M}$ (Table 2). Compounds 15, 17, 27, and 28 are slightly less active as inhibitors of tubulin assembly than isoCA4 and $\mathrm{CA}-4\left(\mathrm{IC}_{50}: 1\right.$ and $2 \mu \mathrm{M}$, respectively). However, comparison of the $I C_{50}$ values for isoerianin $3 a$ and $C A-4$ or isoCA-4 indicates that $\mathbf{3} \mathbf{a}$ is similar to isoCA-4 and may act as a cytotoxic agent through inhibition of tubulin polymerization. 
Table 2. Cytotoxic activity and inhibition of tubulin polymerization of selected compounds.

\begin{tabular}{|c|c|c|c|c|c|c|c|}
\hline \multirow[t]{2}{*}{ Compd } & \multicolumn{6}{|c|}{$\mathrm{Gl}_{50}[\mathrm{~nm}]^{[\mathrm{a}]}$} & \multirow{2}{*}{$\operatorname{ITP} I C_{50}[\mu \mathrm{M}]^{[c]}$} \\
\hline & HCT-116 ${ }^{[b]}$ & $\mathrm{K} 562^{[\mathrm{b}]}$ & $\mathrm{H} 1299^{[b]}$ & $M B 435^{[b]}$ & $M B 231^{[b]}$ & HUVEC $^{[b]}$ & \\
\hline 3 (isoerianin) & $28 \pm 2$ & $25 \pm 1.6$ & $40 \pm 2.8$ & $35 \pm 2.2$ & $35 \pm 2.1$ & $45 \pm 3.5$ & $3 \pm 0.5$ \\
\hline 4 & $100 \pm 8.5$ & $47 \pm 2.8$ & $50 \pm 3.2$ & $54 \pm 3.5$ & $41 \pm 2.5$ & $70 \pm 4.6$ & $N D^{[e]}$ \\
\hline 15 & $29 \pm 1.7$ & $32 \pm 1.7$ & $42 \pm 2.9$ & $33 \pm 2.1$ & $32 \pm 1.8$ & $15 \pm 0.9$ & $20 \pm 4$ \\
\hline 17 & $60 \pm 4.5$ & $20 \pm 1.4$ & $60 \pm 3.6$ & $50 \pm 3.2$ & $50 \pm 3.1$ & $30 \pm 2.2$ & $13 \pm 2$ \\
\hline 27 & $50 \pm 3.1$ & $15 \pm 0.9$ & $40 \pm 2.4$ & $35 \pm 1.8$ & $35 \pm 1.9$ & $25 \pm 1.8$ & $30 \pm 7$ \\
\hline 28 & $30 \pm 1.8$ & $12 \pm 1.1$ & $30 \pm 1.8$ & $35 \pm 2.1$ & $35 \pm 2.2$ & $25 \pm 1.7$ & $23 \pm 5$ \\
\hline 1a $(C A-4)^{[d]}$ & $2 \pm 0.2$ & $4 \pm 0.21$ & $5 \pm 0.21$ & $3 \pm 0.15$ & $3 \pm 0.17$ & $2.5 \pm 0.19$ & $1 \pm 0.1$ \\
\hline $2 a(\text { iso } C A-4)^{[d]}$ & $2 \pm 0.15$ & $5 \pm 0.26$ & $5 \pm 0.18$ & $4 \pm 0.27$ & $4 \pm 0.31$ & $1.5 \pm 0.1$ & $2 \pm 0.3$ \\
\hline $\operatorname{erianin}^{[\mathrm{d}]}$ & $44 \pm 3$ & $36 \pm 2.2$ & $42 \pm 2.9$ & $31 \pm 1.8$ & $49 \pm 2.9$ & $10 \pm 0.9$ & $1.5 \pm 0.2$ \\
\hline
\end{tabular}

[a] Compound concentration required to decrease cell growth by $50 \%$ following treatment with drug for $72 \mathrm{~h}$; values represent the average \pm SEM of three experiments. [b] HCT-116: colon carcinoma; K562: myelogenous leukemia; H1299: non-small-cell lung carcinoma; MDA-MB435: breast cancer; MDAMB231: hormone-independent breast cancer; HUVEC: human umbilical vein endothelial cell. [c] ITP: inhibition of tubulin polymerization. IC ${ }_{50}$ : compound concentration required to decrease the rate of microtubule assembly by $50 \%$; values represent the average $\pm \mathrm{SEM}$ of three experiments. [d] The $\mathrm{Gl} \mathrm{I}_{50}$ and $\mathrm{IC}_{50}$ values (cytotoxicity and ITP, respectively) for CA-4, isoCA-4, and erianin were determined in this study. [e] Not determined.

\section{Cell-cycle analysis and apoptosis}

Because molecules that exhibit effects toward tubulin polymerization cause alteration of cell-cycle parameters with preferential $\mathrm{G}_{2} / \mathrm{M}$ blockade, flow cytometry analysis was performed to determine the effect of the most active compound $3 \mathrm{a}$ on $\mathrm{K} 562$ and H1299 cells (Figure 2). This effect was evaluated after $24 \mathrm{~h}$ treatment with $3 \mathrm{a}$ at various concentrations. The lowest concentration of $3 \mathbf{a}(5 \mathrm{~nm})$ induced no alteration in the distribution of $\mathrm{H} 1299$ and $\mathrm{K} 562$ cells through the cell cycle, whereas at a 10-fold higher concentration ( $50 \mathrm{~nm}) 3 \mathrm{a}$ arrested the majori- ty of cells in the $\mathrm{G}_{2} / \mathrm{M}$ phase ( $87 \%$ for $\mathrm{H} 1299,70 \%$ for $\mathrm{K} 562$ ). The observed effects of $\mathbf{3} \mathbf{a}$ on cell-cycle progression correlate well with its strong antiproliferative and antitubulin activities. This result is in agreement with the similar properties reported previously for the majority of antimitotic agents.

Cell-cycle arrest in the $G_{2} / M$ phase is frequently followed by DNA fragmentation and other morphological features of apoptosis. Therefore, we investigated the effect of $3 a, 17,27$, and 28 at various concentrations $(5,10,50$, and $100 \mathrm{~nm})$ on the induction of apoptosis in $\mathrm{H} 1299$ and K562 cancer cells by using

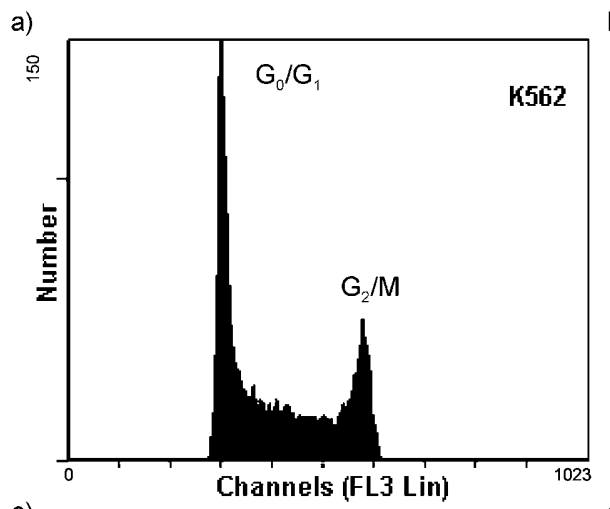

c)

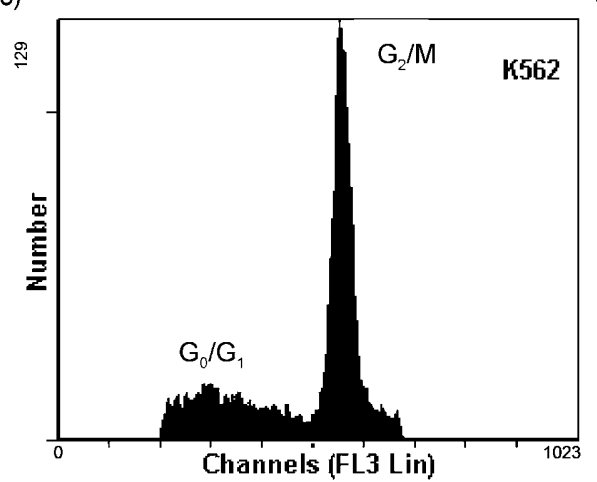

b)

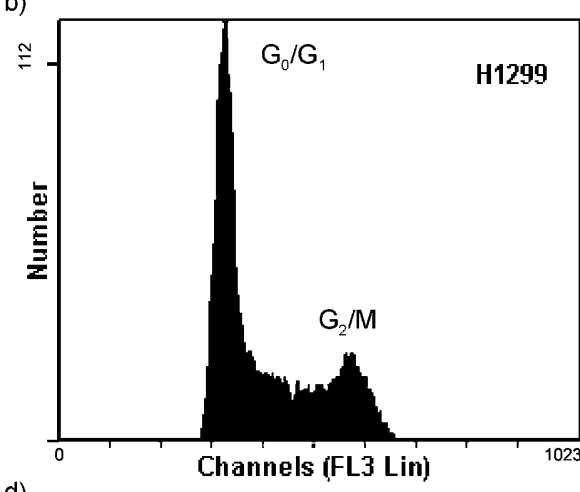

d)

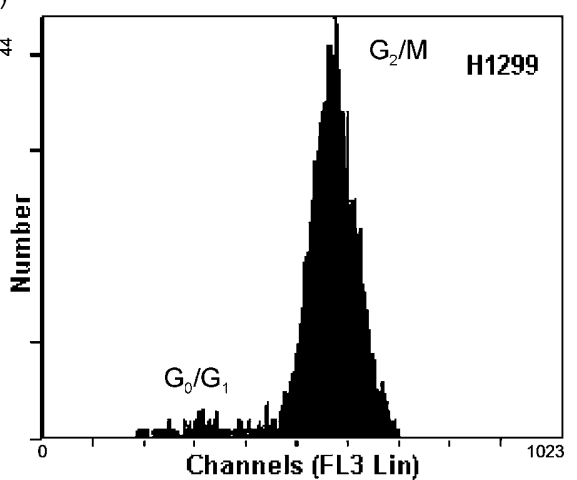

Figure 2. Effect on cell cycle as determined by flow cytometry: untreated cells, a) K562 and b) H1299, were taken as control; treatment of c) $\mathrm{K} 562$ and d) $\mathrm{H} 1299$ cells with isoerianin ( $3 \mathrm{a}$ ) at a concentration of $50 \mathrm{nM}$.

standard assays for caspases 3 and $7 .{ }^{[20]}$ The activity of caspases 3 and 7 was measured by monitoring the cleavage of the profluorescent DEVD peptide-rhodamine 110 substrate in cancer cells. The results presented in Figure 3 show that treatment of cancer cells with compounds $\mathbf{3}$ a, 17, 27, and 28 promotes the cleavage of pro-caspases in H1299 and K562 cells. Notably, all isoerianin derivatives were more active as apoptosis-inducing agents in the $\mathrm{H} 1299$ cell line than in the $\mathrm{K} 562$ line, previously described as being resistant to apoptosis induction by a variety of cytotoxic agents. ${ }^{[21]}$ A pronounced processing of pro-caspases was observed at a concentration of $50 \mathrm{~nm}$, indicating that this effect is dose-dependent. Isoerianin $\mathbf{3 a}$ at $50 \mathrm{~nm}$ seems to be the most promising apoptotic agent in this series because it elicited a 12- to 65-fold increase in caspase activity in $\mathrm{K} 562$ and 
a)

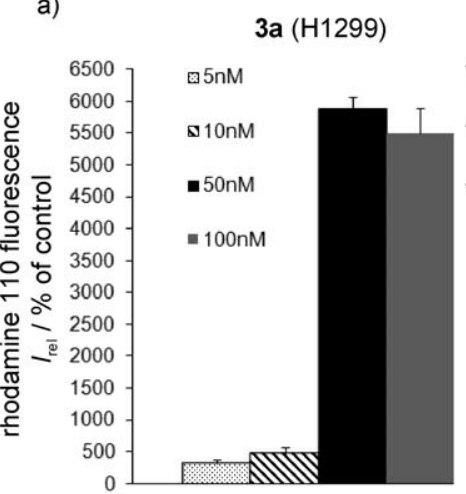

c)

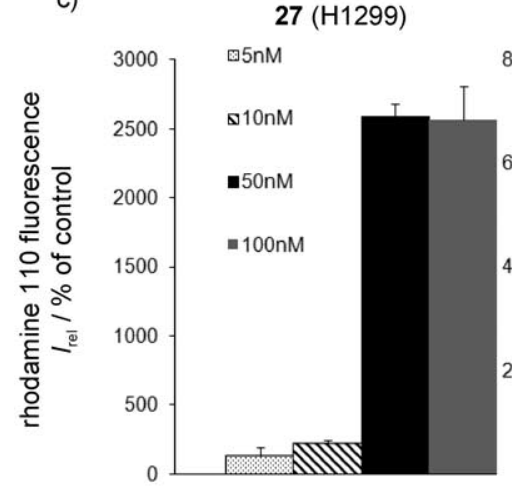

3a (K562)

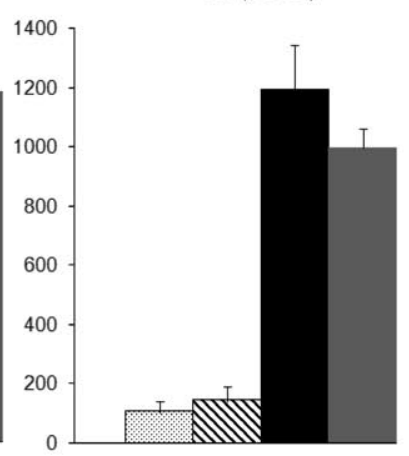

27 (K562)

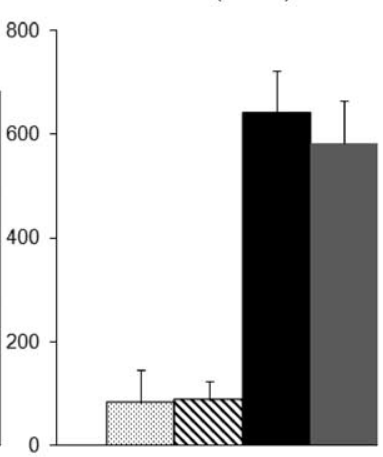

b)

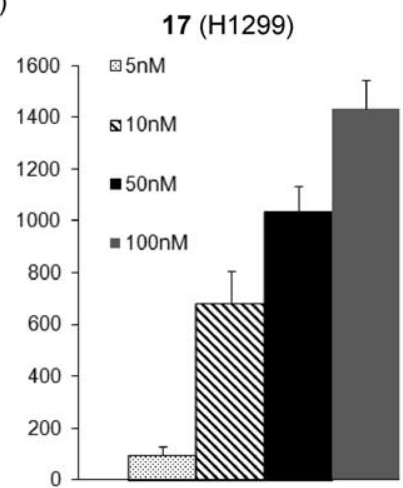

d)

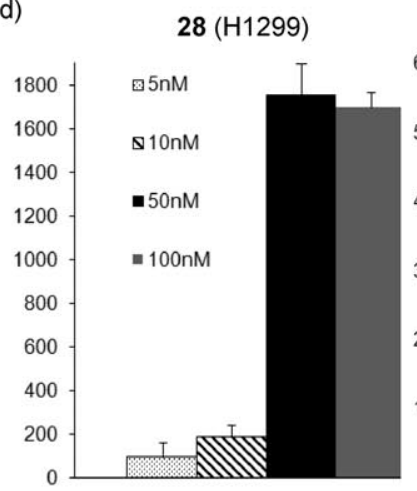

17 (K562)

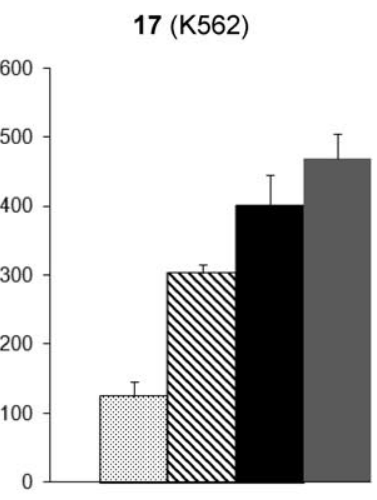

28 (K562)

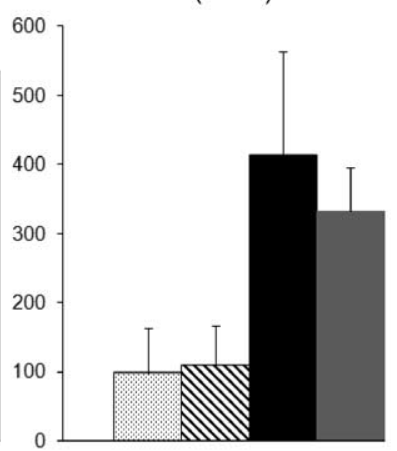

Figure 3. Apoptotic effects of selected compounds in $\mathrm{H} 1299$ and $\mathrm{K} 562$ cells. Results are expressed as a percentage of apoptotic cells detected following $24 \mathrm{~h}$ treatment with a) $\mathbf{3}$ a, b) $\mathbf{1 7}$, c) $\mathbf{2 7}$, and d) $\mathbf{2 8}$ at various concentrations as indicated.

H1299 cell lines, respectively. These results clearly indicate that in addition to their antiproliferative and antitubulin effects, the treatment of cancer cells with these drugs activate caspase activity, leading to programmed cell death.

\section{Effect on HUVEC formation}

The ability of endothelial cells to form tubular structures when plated on a Matrigel matrix allows observation of the three-dimensional organization of endothelial cells and offers an in vitro model of angiogenesis. ${ }^{[22]}$ When seeded on Matrigel, flattened endothelial cells aggregate to form a reticular vascular network of capillary-like vessels (Figure 4). To evaluate whether our lead isoerianin compound $\mathbf{3} \mathbf{a}$ can affect newly formed blood vessels, the in vitro assay of tube formation by HUVECs was performed. Preliminary results indicate that the treatment of HUVECs with isoerianin $3 \mathrm{a}$ for $3 \mathrm{~h}$ at sub-micromolar concentrations clearly inhibits the endothelial cell tube formation. Indeed, the number of branching junctions formed by HUVECs on the Matrigel was significantly decreased by the action of isoerianin in a dose-dependent manner (Figure 4).

As was observed for CA-4 and isoCA-4, the X-ray crystal structure of isoerianin $\mathbf{3}$ a suggests that the conformation of this 1,1-diarylethane derivative is non-planar (Figure 5). The crystal structure reveals that the planes of the phenyl rings are inclined to each other (dihedral angle $=77^{\circ}$ ). For comparison, the respective dihedral angles between the two phenyl planes
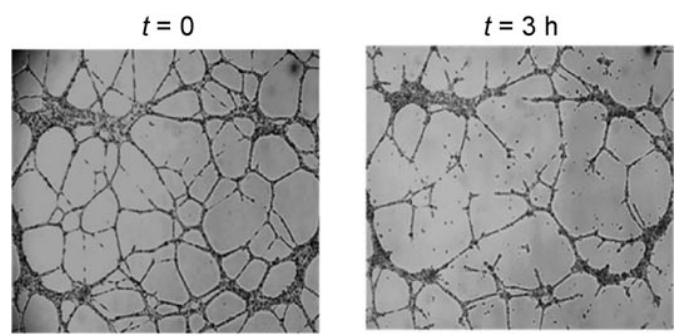

[isoerianin $]=0.5 \mu \mathrm{M}$
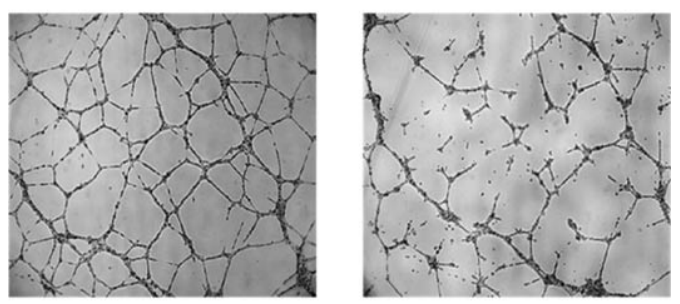

[isoerianin $]=1.0 \mu \mathrm{M}$

Figure 4. Inhibition of HUVEC tube formation on a Matrigel by isoerianin 3 a at 0.5 and $1.0 \mu \mathrm{M}$. Images were taken $3 \mathrm{~h}$ after addition of compound $3 \mathrm{a}$.

in $\mathrm{CA}-4^{[8]}$ and isoCA $-4^{[12]}$ are $53^{\circ}$ and $68^{\circ}$. We believe that the dihedral angles in the series of 1,1-diarylethanes are highly important for the design of antimitotic drugs, relative to the natural CA-4. Adopting the conformation found in its X-ray crystal structure, isoerianin was computationally docked inside the 


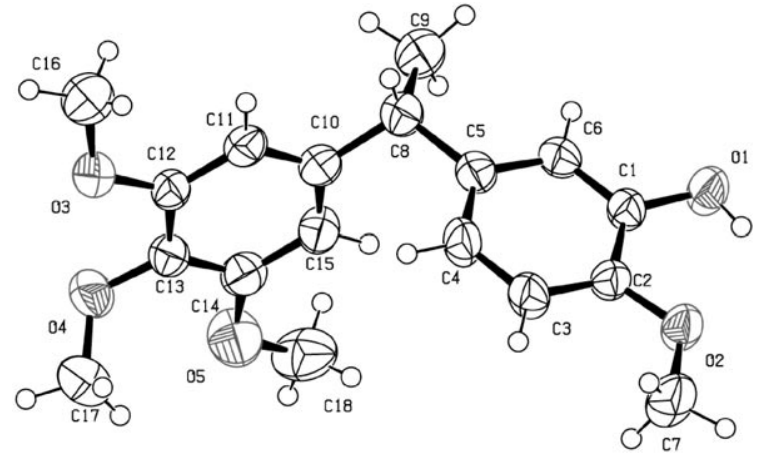

Figure 5. X-ray crystal structure of isoerianin $3 \mathrm{a}$; non-hydrogen atoms are labeled using a crystallographic numbering scheme.

colchicine binding site. For this purpose, the X-ray structure of tubulin-colchicine complex was used (PDB ID: 1SA0). ${ }^{[23]}$

Figure 6 shows the docking-derived superimposition of isoerianin, isoCA-4, and colchicine (green, blue, and orange, respectively). We recently published the close fit between isoCA4 and the colchicine $\mathrm{X}$-ray structure, ${ }^{[12]}$ and as expected, isoer-

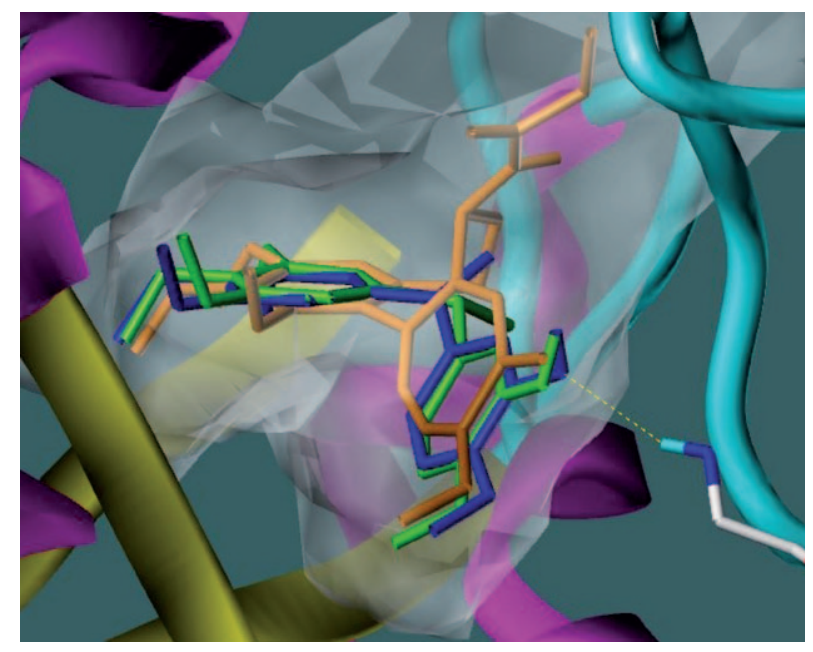

Figure 6. Putative binding mode of isoerianin (green), isoCA-4 (blue), and colchicine (orange) in the colchicine binding site.

ianin 3 a shows good superimposition with both of them in the binding site (Figure 6). As previously reported for a set of colchicine site inhibitors, ${ }^{[24]}$ the 3,4,5-trimethoxyphenyl moieties occupy very similar Cartesian space. Hydroxy and methoxy groups belonging to the rest of the system are also well fitted. Hydroxy groups belonging to isoerianin and isoCA-4 show a hydrogen bond with the backbone of Val 181 as proposed by Nguyen et al. ${ }^{[24]}$

\section{Conclusions}

We synthesized a series of 1,1-diarylethane compounds bearing structural similarity to the isocombretastatins and evaluated their biological activities. As was observed for the CA-4 series, we demonstrated that it is possible to transfer the $B$ ring of natural erianin from the $\mathrm{C} 2$ to the $\mathrm{C} 1$ position with no loss of activity. The most biologically active agent was isoerianin 3, obtained from the catalytic reduction of isoCA-4, with a minimum inhibitory concentration at the nanomolar level against various human cancer cell lines. Furthermore, the antitubulin activity of isoerianin was found to be similar to that of the parent compound erianin as well as CA-4 and isoCA-4, which may indicate a similarity in the mechanism of action. This result contradicts the previously reported conclusions regarding the necessity for tubulin to recognize the $\mathrm{sp}^{2}$ hybridization $^{[18]}$ introduced by the stilbene or 1,1-diarylethylene bridges. Flow cytometric analysis indicated that isoerianin arrests the cell cycle in the $\mathrm{G}_{2} / \mathrm{M}$ phase in $\mathrm{H} 1299$ and $\mathrm{K} 562$ cells. Furthermore, isoerianin and other derivatives were characterized as strongly apoptotic agents promoting the cleavage of pro-caspase 3 in $\mathrm{K} 562$ and $\mathrm{H} 1299$ cells.

From a chemical point of view, the preparation of isoerianin $3 \mathbf{a}$ is particularly simple and was carried out by the racemic catalytic reduction of isoCA-4, as both enantiomers display similar cytotoxicities. In vivo tests of water-soluble phosphate 4 are currently underway in our research group to elucidate the anticancer activity of this compound in mice.

\section{Experimental Section}

\section{Chemistry}

Melting points $(\mathrm{mp})$ were recorded on a Büchi B-450 apparatus and are uncorrected. NMR spectra were performed on a Bruker AMX $200\left({ }^{1} \mathrm{H}, 200 \mathrm{MHz} ;{ }^{13} \mathrm{C}, 50 \mathrm{MHz}\right)$, Bruker AVANCE 300 or Bruker AVANCE $400\left({ }^{1} \mathrm{H}, 400 \mathrm{MHz} ;{ }^{13} \mathrm{C}, 100 \mathrm{MHz}\right)$. Unless otherwise stated, $\mathrm{CDCl}_{3}$ was used as solvent. Chemical shifts $(\delta)$ are reported in $\mathrm{ppm}$, and the following abbreviations are used: singlet (s), doublet $(d)$, triplet $(t)$, multiplet $(m)$. Elemental analyses $(C, H, N)$ were performed with a PerkinElmer 240 analyzer at the microanalysis service of the Faculty of Pharmacy at Châtenay-Malabry (France), and are within $0.4 \%$ of the theoretical values unless otherwise stated. Mass spectra were obtained using a Bruker Esquire electrospray ionization apparatus. Thin-layer chromatography (TLC) was performed on silica gel 60 plates with a fluorescent indicator and visualized under a UVP Mineralight UVGL-58 lamp $(\lambda=254 \mathrm{~nm})$ and with a $7 \%$ solution of phosphomolybdic acid in EtOH. Flash chromatography was performed with silica gel $60(40-63 \mu \mathrm{m}, 230-400$ mesh ASTM) at medium pressure (200 mbar). All solvents were distilled and stored over $4 \AA$ molecular sieves before use. All reagents were obtained from commercial suppliers unless otherwise stated. Organic extracts were, in general, dried over $\mathrm{MgSO}_{4}$ or $\mathrm{Na}_{2} \mathrm{SO}_{4}$.

\section{Synthesis of isoerianin derivatives 3-28}

Isoerianin derivatives $\mathbf{3} \mathbf{a}$ and $\mathbf{5 - 2 6}$ were prepared from the reduction of known 1,1-diarylethylenes $\mathbf{2}^{[11,25]}$ as follows: A solution of 1,1-diarylethylenes $2(1 \mathrm{mmol})$ in EtOAc $(15 \mathrm{~mL})$ was hydrogenated, at atmospheric pressure, in the presence of $\mathrm{Pd} / \mathrm{C}(5 \mathrm{mg})$. After filtration, the solution was concentrated under reduced pressure, and the residue was purified by flash chromatography.

2-Methoxy-5-[1-(3,4,5-trimethoxyphenyl)ethyl]phenol (isoerianin $3 \mathrm{a}):(311 \mathrm{mg}, 98 \%) ; R_{\mathrm{f}}=0.4$ (cyclohexane/EtOAc 7:3); ${ }^{1} \mathrm{H}$ NMR $\left(300 \mathrm{MHz}, \mathrm{CDCl}_{3}\right): \delta=1.58(\mathrm{~d}, 3 \mathrm{H}, J=7.2 \mathrm{~Hz}), 3.81(\mathrm{~s}, 9 \mathrm{H}), 3.83(\mathrm{~s}$, $3 \mathrm{H}), 3.88(\mathrm{q}, 1 \mathrm{H}, J=7.2 \mathrm{~Hz}), 5.60(\mathrm{~s}, 1 \mathrm{H}), 6.43(\mathrm{~s}, 2 \mathrm{H}), 6.70(\mathrm{dd}, 1 \mathrm{H}$, 
$J=10.2 \mathrm{~Hz}, J=2.2 \mathrm{~Hz}), 6.78(\mathrm{~d}, 1 \mathrm{H}, J=10.2 \mathrm{~Hz}), 6.81(\mathrm{~d}, 1 \mathrm{H}, J=$ $2.2 \mathrm{~Hz}) ;{ }^{13} \mathrm{C} \mathrm{NMR}\left(75 \mathrm{MHz}, \mathrm{CDCl}_{3}\right): \delta=21.0,43.4,54.9,55.1$ (2), 59.8, 103.6 (2), 109.5, 112.8, 117.8, 127.8, 135.2, 138.7, 141.2 (2), 143.9, 144.4, 152.0; MS (ESI) $[\mathrm{M}+\mathrm{Na}]^{+}=341$; Anal. calcd for $\mathrm{C}_{18} \mathrm{H}_{22} \mathrm{O}_{5}$ : C 67.91, H 6.97, found: C 67.91, H 6.92

2-Methoxy-5-[1-(3,4,5-trimethoxyphenyl)ethyl]phenyldihydrogen phosphate (4): $(279 \mathrm{mg}, \quad 70 \%) ; R_{\mathrm{f}}=0.1 \quad(\mathrm{MeOH} / \mathrm{EtOAC} \quad 2: 98)$ ${ }^{1} \mathrm{H}$ NMR $\left(300 \mathrm{MHz},\left(\mathrm{CD}_{3}\right)_{2} \mathrm{CO}\right): \delta=1.40(\mathrm{~m}, 3 \mathrm{H}), 3.50(\mathrm{~s}, 3 \mathrm{H}), 3.61(\mathrm{~s}$, $9 \mathrm{H}), 3.95(\mathrm{~m}, 1 \mathrm{H}), 6.40(\mathrm{~m}, 2 \mathrm{H}), 6.75-6.90(\mathrm{~m}, 2 \mathrm{H}), 7.10-7.30(\mathrm{~m}$, $1 \mathrm{H}) ;{ }^{13} \mathrm{C}$ NMR $\left(75 \mathrm{MHz},\left(\mathrm{CD}_{3}\right)_{2} \mathrm{CO}\right): \delta=25.3,48.0,59.4$ (3), 63.5, 108.7 (2), 116.7, 124.3, 127.8, 140.5, 142.9, 144.2, 146.1, 153.1, 157.2 (2); MS (ESI-) $[M-H]^{-}=397$; Anal. calcd for $\mathrm{C}_{18} \mathrm{H}_{23} \mathrm{O}_{8} \mathrm{P}: \mathrm{C} 54.27, \mathrm{H}$ 5.827, found: C 54.09, H 5.73 .

5-[1-(3-Fluoro-4-methoxyphenyl)ethyl]-1,2,3-trimethoxybenzene (5): $\quad(310 \mathrm{mg}, \quad 97 \%) ; \quad R_{\mathrm{f}}=0.6 \quad$ (cyclohexane/EtOAc 7:3); ${ }^{1} \mathrm{H}$ NMR $\left(300 \mathrm{MHz}, \mathrm{CDCl}_{3}\right): \delta=1.50(\mathrm{~d}, 3 \mathrm{H}, J=7.2 \mathrm{~Hz}), 3.73(\mathrm{~s}, 6 \mathrm{H}), 3.74(\mathrm{~s}$, $3 \mathrm{H}), 3.78(\mathrm{~s}, 3 \mathrm{H}), 3.95(\mathrm{q}, 1 \mathrm{H}, J=7.2 \mathrm{~Hz}), 6.32(\mathrm{~s}, 2 \mathrm{H}), 6.68-6.90(\mathrm{~m}$ $3 \mathrm{H}) ;{ }^{13} \mathrm{C}$ NMR $\left(75 \mathrm{MHz}, \mathrm{CDCl}_{3}\right): \delta=22.0,44.1,56.1$, (2) $56.3,60.8$, $104.6(2), 113.3,115.2(\mathrm{~d}, J=18.1 \mathrm{~Hz}), 122.8(\mathrm{~d}, J=3.0 \mathrm{~Hz}), 136.4$ $139.4,141.7$ (2), 145.7, 150.6, 153.1, 153.8; MS (ESI) $[M+N a]^{+}=343$; Anal. calcd for $\mathrm{C}_{18} \mathrm{H}_{21} \mathrm{FO}_{4}$ : C 67.49, H 6.61, found: C 67.39, H 6.52 .

\section{1,2,3-Trimethoxy-5-[1-(4-methoxyphenyl)ethyl]benzene}

(281 mg, 93\%); $R_{\mathrm{f}}=0.5\left(\mathrm{CH}_{2} \mathrm{Cl}_{2}\right) ;{ }^{1} \mathrm{H}$ NMR $\left(300 \mathrm{MHz}, \mathrm{CDCl}_{3}\right): \delta=1.50$ $(\mathrm{d}, 3 \mathrm{H}, J=7.2 \mathrm{~Hz}), 3.66(\mathrm{~s}, 6 \mathrm{H}), 3.72(\mathrm{~s}, 3 \mathrm{H}), 3.74(\mathrm{~s}, 3 \mathrm{H}), 3.95(\mathrm{q}$, $1 \mathrm{H}, J=7.2 \mathrm{~Hz}), 6.30(\mathrm{~s}, 2 \mathrm{H}), 6.75(\mathrm{~d}, 1 \mathrm{H}, J=7.2 \mathrm{~Hz}), 7.05(\mathrm{~d}, 1 \mathrm{H}, J=$ $10.2 \mathrm{~Hz}) ;{ }^{13} \mathrm{C}$ NMR $\left(75 \mathrm{MHz}, \mathrm{CDCl}_{3}\right): \delta=22.2,44.2,55.2,56.1$ (2), 60.8, 104.3 (2), 113.7 (2), 128.4 (2), 136.2, 138.3, 142.5 (2), 153.0, 157.9; MS (ESI) $[M+N a]^{+}=325$; Anal. calcd for $\mathrm{C}_{18} \mathrm{H}_{2} \mathrm{O}_{4}: \mathrm{C} 71.50, \mathrm{H}$ 7.33, found: C 71.39, H 7.26.

1,2,3-Trimethoxy-5-(1-p-tolylethyl)benzene (7): (285 mg, 99\%); $R_{\mathrm{f}}=0.5\left(\mathrm{CH}_{2} \mathrm{Cl}_{2}\right) ;{ }^{1} \mathrm{H}$ NMR $\left(300 \mathrm{MHz}, \mathrm{CDCl}_{3}\right): \delta=1.52(\mathrm{~d}, 3 \mathrm{H}, J=$ $7.2 \mathrm{~Hz}), 2.20(\mathrm{~s}, 3 \mathrm{H}), 3.70(\mathrm{~s}, 6 \mathrm{H}), 3.72(\mathrm{~s}, 3 \mathrm{H}), 3.94(\mathrm{q}, 1 \mathrm{H}, J=$ $7.2 \mathrm{~Hz}), 6.35(\mathrm{~s}, 2 \mathrm{H}), 6.98-7.05(\mathrm{~m}, 4 \mathrm{H}) ;{ }^{13} \mathrm{C} \mathrm{NMR}\left(75 \mathrm{MHz}, \mathrm{CDCl}_{3}\right)$ : $\delta=21.0$, 22.1, 44.7, 56.1 (2), 60.8, 104.7 (2), 127.3 (2) 128.7 (2), 135.6, 136.3, 142.3, 143.2, 154.2 (2); MS (ESI) $[M+N a]^{+}=309$; Anal. calcd for $\mathrm{C}_{18} \mathrm{H}_{22} \mathrm{O}_{3}$ : C 75.50, H 7.74, found: C 75.40, H 7.66.

5-[1-(3,4,5-Trimethoxyphenyl)ethyl]benzo[ $d][1,3]$ dioxole (8): (272 mg, 86\%); $R_{\mathrm{f}}=0.4\left(\mathrm{CH}_{2} \mathrm{Cl}_{2}\right) ;{ }^{1} \mathrm{H}$ NMR $\left(300 \mathrm{MHz}, \mathrm{CDCl}_{3}\right): \delta=1.52$ $(\mathrm{d}, 3 \mathrm{H}, J=7.2 \mathrm{~Hz}), 3.75(\mathrm{~s}, 9 \mathrm{H}), 4.00(\mathrm{q}, 1 \mathrm{H}, J=7.2 \mathrm{~Hz}), 5.80(\mathrm{~s}, 2 \mathrm{H})$, $6.35(\mathrm{~s}, 2 \mathrm{H}), 6.62-6.68(\mathrm{~m}, 3 \mathrm{H}) ;{ }^{13} \mathrm{C}$ NMR $\left(75 \mathrm{MHz}, \mathrm{CDCl}_{3}\right): \delta=22.1$, 44.7, 56.1 (2), 60.8, 100.8, 104.6 (2), 108.2, 120.2, 136.3, 140.3, 142.1, 145.8, 147.6, 153.0 (2); MS (ESI) $[\mathrm{M}+\mathrm{Na}]^{+}=339$; Anal. calcd for $\mathrm{C}_{18} \mathrm{H}_{20} \mathrm{O}_{5}$ : C 68.34, H 6.37, found: C 68.29, H 6.31.

2-[1-(3,4,5-Trimethoxyphenyl)ethyl]naphthalene (9): $\quad(293 \mathrm{mg}$ $91 \%) ; R_{\mathrm{f}}=0.5\left(\mathrm{CH}_{2} \mathrm{Cl}_{2}\right) ;{ }^{1} \mathrm{H}$ NMR $\left(300 \mathrm{MHz}, \mathrm{CDCl}_{3}\right): \delta=1.62(\mathrm{~d}, 3 \mathrm{H}$, $J=7.2 \mathrm{~Hz}), 3.70(\mathrm{~s}, 6 \mathrm{H}), 3.74(\mathrm{~s}, 3 \mathrm{H}), 4.16(\mathrm{q}, 1 \mathrm{H}, J=7.2 \mathrm{~Hz}), 6.38(\mathrm{~s}$, $2 \mathrm{H}), 7.22(\mathrm{dd}, 1 \mathrm{H}, J=8.5 \mathrm{~Hz}, J=2.2 \mathrm{~Hz}), 7.28-7.42(\mathrm{~m}, 2 \mathrm{H}), 7.61(\mathrm{~s}$, $1 \mathrm{H}), 7.64-7.77(\mathrm{~m}, 3 \mathrm{H}) ;{ }^{13} \mathrm{C} \mathrm{NMR}\left(75 \mathrm{MHz}, \mathrm{CDCl}_{3}\right): \delta=21.9,45.1$, 56.1 (2), 60.6, 104.9, 125.3, 125.5, 126.0, 126.7, 127.6, 127.8, 128.0, 132.2, 133.6, 136.4, 141.2, 143.3, 153.2 (2); MS (ESI) $[M+N a]^{+}=345$; Anal. calcd for $\mathrm{C}_{21} \mathrm{H}_{22} \mathrm{O}_{3}$ : C 78.23, H 6.88, found: C 78.19, $\mathrm{H} 6.84$.

6-[1-(3,4,5-Trimethoxyphenyl)ethyl]quinoline (10): $\quad(174 \mathrm{mg}$ $54 \%) ; R_{\mathrm{f}}=0.4\left(\mathrm{Et}_{2} \mathrm{O}\right) ;{ }^{1} \mathrm{H}$ NMR $\left(300 \mathrm{MHz}, \mathrm{CDCl}_{3}\right): \delta=1.76(\mathrm{~d}, 3 \mathrm{H}, J=$ $7.2 \mathrm{~Hz}), 3.76(\mathrm{~s}, 3 \mathrm{H}), 3.80(\mathrm{~s}, 6 \mathrm{H}), 4.36(\mathrm{q}, 1 \mathrm{H}, J=7.0 \mathrm{~Hz}), 6.61(\mathrm{~s}$, $2 \mathrm{H}), 7.53(\mathrm{dd}, 1 \mathrm{H}, J=4.4 \mathrm{~Hz}, J=8.3 \mathrm{~Hz}), 7.70(\mathrm{dd}, 1 \mathrm{H}, J=1.8 \mathrm{~Hz}, J=$ $8.8 \mathrm{~Hz}), 7.87(\mathrm{~s}, 1 \mathrm{H}), 7.96(\mathrm{~d}, 1 \mathrm{H}, J=8.8 \mathrm{~Hz}), 8.36(\mathrm{~d}, 1 \mathrm{H}, J=8.0 \mathrm{~Hz})$, $8.81(\mathrm{dd}, 1 \mathrm{H}, J=1.5 \mathrm{~Hz}, J=4.3 \mathrm{~Hz}) ;{ }^{13} \mathrm{C}$ NMR $(75 \mathrm{MHz}, \mathrm{MeOD}): \delta=$ $22.3,46.2,56.6(2 \mathrm{C}), 61.1,106.2(2 \mathrm{C}), 122.6,126.4,128.9,129.9$, $132.1,138.3,143.4,146.7(2), 150.6,154.6(2 \mathrm{C})$; MS (APCI) $[M+\mathrm{H}]^{+}$
=324; Anal. calcd for $\mathrm{C}_{20} \mathrm{H}_{21} \mathrm{NO}_{3}$ : C 74.28, N 4.33, $\mathrm{H}$ 6.55, found: $\mathrm{C}$ 74.18, N 4.21, H 6.42 .

3-Methoxy-6-[1-(3,4,5-trimethoxyphenyl)ethyl]benzene-1,2-diol (11): $(317 \mathrm{mg}, 95 \%) ; R_{\mathrm{f}}=0.45$ (cyclohexane/EtOAc 1:1); ${ }^{1} \mathrm{H}$ NMR $\left(\mathrm{CDCl}_{3} 300 \mathrm{MHz}\right): \delta=1.57(\mathrm{~d}, 3 \mathrm{H}, J=7.2 \mathrm{~Hz}), 3.82(\mathrm{~s}, 9 \mathrm{H}), 3.86(\mathrm{~s}$, $3 \mathrm{H}), 4.39(\mathrm{q}, 1 \mathrm{H}, J=7.0 \mathrm{~Hz}), 5.37(\mathrm{~s}, 2 \mathrm{H}), 6.44(\mathrm{~d}, 1 \mathrm{H}, J=8.6 \mathrm{~Hz})$, $6.50(\mathrm{~s}, 2 \mathrm{H}), 6.65(\mathrm{~d}, 1 \mathrm{H}, J=8.6 \mathrm{~Hz}) ;{ }^{13} \mathrm{C}$ NMR $\left(75 \mathrm{MHz}, \mathrm{CDCl}_{3}\right): \delta=$ 21.0, 37.9, 56.1 (3C), 60.8, 102.5, 104.7 (2C), 117.8, 126.1, 132.3, 136.2, 141.6, 141.9, 145.3, 153.0 (2C); MS (APCI) $[\mathrm{M+H}]^{+}=335$; Anal. calcd for $\mathrm{C}_{18} \mathrm{H}_{22} \mathrm{O}_{6}$ : $\mathrm{C} 64.66, \mathrm{H} 6.63$, found: $\mathrm{C} 64.40, \mathrm{H} 6.48$.

2-Methoxy-5-[1-(3,4,5-trimethoxyphenyl)ethyl]phenyl acetate (12): $(324 \mathrm{mg}, 90 \%) ; R_{\mathrm{f}}=0.5\left(\mathrm{CH}_{2} \mathrm{Cl}_{2}\right) ;{ }^{1} \mathrm{H} \mathrm{NMR}\left(300 \mathrm{MHz}, \mathrm{CDCl}_{3}\right)$ : $\delta=1.51(\mathrm{~d}, 3 \mathrm{H}, J=7.2 \mathrm{~Hz}), 2.22(\mathrm{~s}, 3 \mathrm{H}), 3.73(\mathrm{~s}, 3 \mathrm{H}), 3.74(\mathrm{~s}, 6 \mathrm{H})$, $3.75(\mathrm{~s}, 3 \mathrm{H}), 3.95(\mathrm{q}, 1 \mathrm{H}, J=7.2 \mathrm{~Hz}), 6.32(\mathrm{~s}, 2 \mathrm{H}), 6.79-6.83(\mathrm{~m}, 2 \mathrm{H})$, $6.97(\mathrm{dd}, 1 \mathrm{H}, J=8.4 \mathrm{~Hz}, J=1.7 \mathrm{~Hz}) ;{ }^{13} \mathrm{CNMR}\left(75 \mathrm{MHz}, \mathrm{CDCl}_{3}\right): \delta=$ 20.7, 22.1, 38.7, 55.9, 56.1 (2), 60.8, 104.6 (2), 112.2, 121.9, 125.6, $136.3,138.8,139.5,141.9,149.3,153.1(2), 169.0 ; \mathrm{MS}(\mathrm{ESI})[\mathrm{M}+\mathrm{Na}]^{+}$ =383; Anal. calcd for $\mathrm{C}_{20} \mathrm{H}_{24} \mathrm{O}_{6}: \mathrm{C} 66.65, \mathrm{H} \mathrm{6.71}$, found: $\mathrm{C} 66.49, \mathrm{H}$ 6.63.

2-Methoxy-5-[1-(3,4,5-trimethoxyphenyl)ethyl]phenyl diethylcarbamate (13): $(379 \mathrm{mg}, 91 \%) ; R_{\mathrm{f}}=0.5\left(\mathrm{CH}_{2} \mathrm{Cl}_{2}\right) ;{ }^{1} \mathrm{H}$ NMR $(300 \mathrm{MHz}$, $\left.\mathrm{CDCl}_{3}\right): \delta=1.10-1,30(\mathrm{~m}, 6 \mathrm{H}), 1.50(\mathrm{~d}, 3 \mathrm{H}, J=7.2 \mathrm{~Hz}), 3.25-3.45(\mathrm{~m}$, $4 \mathrm{H}), 3.72(\mathrm{~s}, 6 \mathrm{H}), 3.74(\mathrm{~s}, 3 \mathrm{H}), 3.75(\mathrm{~s}, 3 \mathrm{H}), 3.95(\mathrm{q}, 1 \mathrm{H}, J=7.2 \mathrm{~Hz})$, $6.32(\mathrm{~s}, 2 \mathrm{H}), 6.78(\mathrm{~d}, 1 \mathrm{H}, J=8.4 \mathrm{~Hz}), 6.86-6.95(\mathrm{~m}, 2 \mathrm{H}) ;{ }^{13} \mathrm{C} \mathrm{NMR}$ $\left(75 \mathrm{MHz}, \mathrm{CDCl}_{3}\right): \delta=12.7$ (2), 20.9, 22.1, 35.7, 42.9, (2), 55.9, 56.3 (2), 67.8, 105.6 (2), 113.2, 120.9, 126.6, 135.9, 136.3, 137.8, 140.1, 149.3, 153.1 (2), 156.2.0; MS (ESI) $[M+N a]^{+}=440$; Anal. calcd for $\mathrm{C}_{23} \mathrm{H}_{31} \mathrm{NO}_{6}$ : C 66.17, N 3.35, H 7.48, found: C 66.04, N 3.19, H 7.33.

5-Methoxy-2-[1-(3,4,5-trimethoxyphenyl)ethyl]pyridine (14): (302 mg, 99\%); $R_{\mathrm{f}}=0.35 \quad$ (cyclohexane/EtOAc 95:5); ${ }^{1} \mathrm{H}$ NMR $\left(300 \mathrm{MHz}, \mathrm{CDCl}_{3}\right): \delta=1.63(\mathrm{~d}, 3 \mathrm{H}, J=7.2 \mathrm{~Hz}), 3.75(\mathrm{~s}, 3 \mathrm{H}), 3.81(\mathrm{~s}$, $6 \mathrm{H}), 3.89(\mathrm{~s}, 3 \mathrm{H}), 4.11(\mathrm{q}, 1 \mathrm{H}, J=7.2 \mathrm{~Hz}), 6.55(\mathrm{~s}, 2 \mathrm{H}), 6.75(\mathrm{~d}, 1 \mathrm{H}$, $J=8.6 \mathrm{~Hz}), 7.59(\mathrm{dd}, 1 \mathrm{H}, J=2.3 \mathrm{~Hz}, J=8.6 \mathrm{~Hz}), 8.04(\mathrm{~d}, 1 \mathrm{H}, J=$ $2.3 \mathrm{~Hz}) ;{ }^{13} \mathrm{C}$ NMR $\left(75 \mathrm{MHz}, \mathrm{CDCl}_{3}\right): \delta=22.1,22.0,43.1,54.1,56.6$ (2C), 61.1, 105.8 (2C), 111.4, 136.2, 137.5, 139.9, 143,4, 146.1, 154.5, 164.3 (2C); MS (APCI) $[\mathrm{M}+\mathrm{H}]^{+}=304$; Anal. calcd for $\mathrm{C}_{17} \mathrm{H}_{21} \mathrm{NO}_{4}$ : C $67.31, \mathrm{~N} 4.62, \mathrm{H} 6.98$, found: C 67.25, N 4.55, H 6.92 .

1-Methyl-5-[1-(3,4,5-trimethoxyphenyl)ethyl]-1 H-indole (15): (192 mg, 59\%); $R_{\mathrm{f}}=0.75 \quad$ (cyclohexane/EtOAc 6:4); ${ }^{1} \mathrm{H}$ NMR $\left(300 \mathrm{MHz} \mathrm{CDCl}_{3}\right): \delta=1.67(\mathrm{~d}, 3 \mathrm{H}, J=7.2 \mathrm{~Hz}), 3.74(\mathrm{~s}, 3 \mathrm{H}), 3.76(\mathrm{~s}$, $9 \mathrm{H}), 4.19(\mathrm{q}, 1 \mathrm{H}, J=7.1 \mathrm{~Hz}), 6.38(\mathrm{dd}, 1 \mathrm{H}, J=0.6 \mathrm{~Hz}, J=3.0 \mathrm{~Hz})$, $6.55(\mathrm{~s}, 2 \mathrm{H}), 7.05(\mathrm{dd}, 1 \mathrm{H}, J=1.4 \mathrm{~Hz}, J=8.5 \mathrm{~Hz}), 7.10(\mathrm{~d}, 1 \mathrm{H}, J=$ $3.1 \mathrm{~Hz}), 7.26(\mathrm{~d}, 1 \mathrm{H}, J=8.5 \mathrm{~Hz}), 7,45(\mathrm{~s}, 1 \mathrm{H}) ;{ }^{13} \mathrm{C}$ NMR $(100 \mathrm{MHz}$, $\left.\mathrm{CDCl}_{3}\right): \delta=22.9,32.8,46.3,56.5(2 \mathrm{C}), 61.1,101.6,106.4(2 \mathrm{C}), 110.0$, 112.6, 119.7, 122.8, 130.1, 137.0, 138.2 (2), 145.4, 154.2 (2C); MS (APCI) $[\mathrm{M}+\mathrm{H}]^{+}=326$; Anal. calcd for $\mathrm{C}_{20} \mathrm{H}_{23} \mathrm{NO}_{3}$ : C 73.82, N 4.30, $\mathrm{H}$ 7.12, found: C 73.73, N 4.18, H 7.04 .

3-[1-(3,4,5-Trimethoxyphenyl)ethyl]-1 $\mathrm{H}$-indole $\quad$ (16): $\quad$ (247 mg, $79 \%) ; R_{\mathrm{f}}=0.4\left(\mathrm{CH}_{2} \mathrm{Cl}_{2}\right) ;{ }^{1} \mathrm{H}$ NMR $\left(300 \mathrm{MHz}, \mathrm{CDCl}_{3}\right): \delta=1.55(\mathrm{~d}, 3 \mathrm{H}$, $J=7.2 \mathrm{~Hz}), 3.72(\mathrm{~s}, 6 \mathrm{H}), 3.74(\mathrm{~s}, 3 \mathrm{H}), 4.20(\mathrm{q}, 1 \mathrm{H}, J=7.1 \mathrm{~Hz}), 6.43(\mathrm{~s}$, $2 \mathrm{H}), 6.92-6.99(\mathrm{~m}, 3 \mathrm{H}), 7.06-7.09(\mathrm{dd}, 1 \mathrm{H}, J=8.1 \mathrm{~Hz}, J=0.9 \mathrm{~Hz})$, $7.15(\mathrm{~d}, 1 \mathrm{H}, J=7.8 \mathrm{~Hz}), 7.27(\mathrm{~d}, 1 \mathrm{H}, J=7.8 \mathrm{~Hz}), 7.95(\mathrm{~s}, 1 \mathrm{H})$; ${ }^{13} \mathrm{C}$ NMR $\left(75 \mathrm{MHz}, \mathrm{CDCl}_{3}\right): \delta=21.8,34.7,56.2(2 \mathrm{C}), 56.6,105.3(2 \mathrm{C})$, $111.0,115.4,119.0,120.2,122.3,127.2,134.6,136.2,136.4,153.0$ (2C); MS (ESI) $[\mathrm{M}+\mathrm{Na}]^{+}=334$; Anal. calcd for $\mathrm{C}_{19} \mathrm{H}_{21} \mathrm{NO}_{3}$ : C 73.29, $\mathrm{N}$ 4.50, H 6.80, found: C 73.09, N 4.33, H 6.60.

2-Methoxy-5-[1-(3,4,5-trimethoxyphenyl)ethyl]benzenamine (17): $(171 \mathrm{mg}, 58 \%) ; R_{\mathrm{f}}=0.15$ (cyclohexane/EtOAc 7:3); ${ }^{1} \mathrm{H}$ NMR $\left(300 \mathrm{MHz}, \mathrm{CDCl}_{3}\right): \delta=1.57(\mathrm{~d}, 3 \mathrm{H}, J=7.2 \mathrm{~Hz}), 3.82(\mathrm{~s}, 12 \mathrm{H}), 3.98(\mathrm{q}$, $1 \mathrm{H}, J=7.2 \mathrm{~Hz}), 6,44(\mathrm{~s}, 2 \mathrm{H}), 6,56(\mathrm{~d}, 1 \mathrm{H}, J=2.1 \mathrm{~Hz}), 6,60(\mathrm{dd}, 1 \mathrm{H}$, 
$J=8.2 \mathrm{~Hz}, J=2.1 \mathrm{~Hz}), 6,72(\mathrm{~d}, 1 \mathrm{H}, J=8.2 \mathrm{~Hz}) ;{ }^{13} \mathrm{C} \mathrm{NMR}(75 \mathrm{MHz}$ $\left.\mathrm{CDCl}_{3}\right): \delta=22.2,44.4,55.5,56.1$ (2), 60.9, 104.6 (2), 110.2, 114.5 $117.1,135.9,136.2,139.0,142.6,145.8,153.0(2) ; \mathrm{MS}$ (ESI) $[\mathrm{M}+\mathrm{Na}]^{+}$ =318; Anal. calcd for $\mathrm{C}_{18} \mathrm{H}_{23} \mathrm{NO}_{4}$ : C 68.12, N 4.41, H 7.30, found: $\mathrm{C}$ 68.00, N 4.29, H 7.19 .

\section{4-Methoxy-2-[1-(3,4,5-trimethoxyphenyl)ethyl]benzenamine} (18): $(282 \mathrm{mg}, 89 \%) ; R_{\mathrm{f}}=0.2\left(\mathrm{CH}_{2} \mathrm{Cl}_{2}\right) ;{ }^{1} \mathrm{H}$ NMR $\left(300 \mathrm{MHz}, \mathrm{CDCl}_{3}\right)$ : $\delta=1.50(\mathrm{~d}, 3 \mathrm{H}, J=7.2 \mathrm{~Hz}), 3.71(\mathrm{~s}, 6 \mathrm{H}), 3.72(\mathrm{~s}, 3 \mathrm{H}), 3.74(\mathrm{~s}, 3 \mathrm{H})$, $3.85(\mathrm{q}, 1 \mathrm{H}, J=7.2 \mathrm{~Hz}), 6.33(\mathrm{~s}, 2 \mathrm{H}), 6.55(\mathrm{~d}, 1 \mathrm{H}, J=8.4 \mathrm{~Hz}), 6.60$ $(\mathrm{dd}, 1 \mathrm{H}, J=8.4 \mathrm{~Hz}, J=2.7 \mathrm{~Hz}), 6.80(\mathrm{~d}, 1 \mathrm{H}, J=2.7 \mathrm{~Hz}) ;{ }^{13} \mathrm{C} \mathrm{NMR}$ $\left(75 \mathrm{MHz}, \mathrm{CDCl}_{3}\right): \delta=21.7,40.7,55.7,56.1$ (2C), 60.8, 104.5, 111.6, $114.1117 .2,131.8,136.5,137.9,141.2$ (2), 153.0, 153.4 (2); MS (ESI) $[\mathrm{M}+\mathrm{Na}]^{+}=340$; Anal. calcd for $\mathrm{C}_{18} \mathrm{H}_{23} \mathrm{NO}_{4}$ : C 68.12, N 4.41, H 7.30, found: C 68.07, N 4.31, H 7.35.

\section{5-Methoxy-2-[1-(3,4,5-trimethoxyphenyl)ethyl]benzenamine} (19): $(273 \mathrm{mg}, 86 \%) ; R_{\mathrm{f}}=0.2\left(\mathrm{CH}_{2} \mathrm{Cl}_{2}\right) ;{ }^{1} \mathrm{H}$ NMR $\left(300 \mathrm{MHz}, \mathrm{CDCl}_{3}\right)$ : $\delta=1.50(\mathrm{~d}, 3 \mathrm{H}, J=7.2 \mathrm{~Hz}), 3.63(\mathrm{~s}, 3 \mathrm{H}), 3.70(\mathrm{~s}, 6 \mathrm{H}), 3.74(\mathrm{~s}, 3 \mathrm{H})$, $3.85(\mathrm{q}, 1 \mathrm{H}, J=7.2 \mathrm{~Hz}), 6.14(\mathrm{~m}, 1 \mathrm{H}), 6.32(\mathrm{~m}, 3 \mathrm{H}), 7.06(\mathrm{~d}, 1 \mathrm{H}, J=$ $8.4 \mathrm{~Hz}) ;{ }^{13} \mathrm{C}$ NMR $\left(75 \mathrm{MHz}, \mathrm{CDCl}_{3}\right): \delta=21.0,39.1,54.1,55.1$ (2C), 59.8, 101.1, 102.8, 103.3 (2), 121.4, 126.8 (2), 135.4, 140.9, 144.5, 152.4 (2), 158.1; MS (ESI) $[M+\mathrm{H}]^{+}=318$; Anal. calcd for $\mathrm{C}_{18} \mathrm{H}_{23} \mathrm{NO}_{4}$ : C 68.12, N 4.41, H 7.30, found: C 68.02, N 4.4.28, H 7.23.

2-Methoxy-5-[1-(7-methoxybenzo[d][1,3]dioxol-5-yl)ethyl]phenol (20): $(239 \mathrm{mg}, 79 \%) ; R_{\mathrm{f}}=0.8 \quad\left(\mathrm{CH}_{2} \mathrm{Cl}_{2} /\right.$ cyclohexane $\left.8: 2\right) ;{ }^{1} \mathrm{H}$ NMR $\left(300 \mathrm{MHz}, \mathrm{CDCl}_{3}\right): \delta=1.55(\mathrm{~d}, 3 \mathrm{H}, J=7.2 \mathrm{~Hz}), 3.85(\mathrm{~s}, 3 \mathrm{H}), 3.86(\mathrm{~s}$, $3 \mathrm{H}), 3.95(\mathrm{q}, 1 \mathrm{H}, J=7.2 \mathrm{~Hz}), 5.60(\mathrm{~m}, 1 \mathrm{H}), 5.90(\mathrm{~s}, 2 \mathrm{H}), 6.39(\mathrm{~m}, 2 \mathrm{H})$, $6.69(\mathrm{dd}, 1 \mathrm{H}, J=8.4 \mathrm{~Hz}, J=1.8 \mathrm{~Hz}), 6.77(\mathrm{~d}, \mathrm{H}, J=8.4 \mathrm{~Hz}), 79(\mathrm{~d}, 1 \mathrm{H}$, $J=1.8 \mathrm{~Hz}) ;{ }^{13} \mathrm{C}$ NMR $\left(75 \mathrm{MHz}, \mathrm{CDCl}_{3}\right): \delta=22.1,44.1,55.9$, 56.6, $101.2,101.6,107.0,110.5,113.7,118.7,139.7,141.4,143.3,144.8$, 145.4, 148.8; MS (APCI) $[M+\mathrm{H}]^{+}=303$; Anal. calcd for $\mathrm{C}_{17} \mathrm{H}_{18} \mathrm{O}_{5}$ : C $67.54, \mathrm{H} 6.00$, found: C $67.20, \mathrm{H} 5.87$.

5-[1-(3,5-Dimethoxyphenyl)ethyl]-2-methoxybenzenamine (21): (252 mg, 88\%); $R_{\mathrm{f}}=0.5 \quad$ (cyclohexane/EtOAc 6:4); ${ }^{1} \mathrm{H}$ NMR $\left(300 \mathrm{MHz}, \mathrm{CDCl}_{3}\right): \delta=1.56(\mathrm{~d}, 3 \mathrm{H}, J=7.2 \mathrm{~Hz}), 3.76(\mathrm{~s}, 6 \mathrm{H}), 3.82(\mathrm{~s}$, $3 \mathrm{H}), 3.95(\mathrm{q}, 1 \mathrm{H}, J=7.2 \mathrm{~Hz}), 6.29(\mathrm{t}, 1 \mathrm{H}, J=2.3 \mathrm{~Hz}), 6.39(\mathrm{~d}, 2 \mathrm{H}, J=$ $2.3 \mathrm{~Hz}), 6.57(\mathrm{~d}, 1 \mathrm{H}, J=2.1 \mathrm{~Hz}), 6.61(\mathrm{dd}, 1 \mathrm{H}, J=2.1 \mathrm{~Hz}, J=8.2 \mathrm{~Hz})$, $6.71(\mathrm{~d}, 1 \mathrm{H}, J=8.2 \mathrm{~Hz}) ;{ }^{13} \mathrm{C} \mathrm{NMR}\left(75 \mathrm{MHz}, \mathrm{CDCl}_{3}\right): \delta=21.844 .4$, 55.2 (2C), 55.5, 97.5, 105.9 (2C), 110.2, 114.5, 117.2, 135.8, 138.8, 145.7, 149.4, $160.6(2 \mathrm{C})$; MS (APCI) $[\mathrm{M}+\mathrm{H}]^{+}=288$; Anal. calcd for $\mathrm{C}_{17} \mathrm{H}_{21} \mathrm{NO}_{3}$ : C 71.06, N 4.87, H 7.37, found: C 70.98, N 4.67, H 7.28.

5-[1-(3-Ethoxy-4-methoxyphenyl)ethyl]-2-methoxybenzenamine (22): $(242 \mathrm{mg}, 80 \%) ; R_{\mathrm{f}}=0.6$ (cyclohexane/EtOAc 6:4); ${ }^{1} \mathrm{H}$ NMR $\left(300 \mathrm{MHz}, \mathrm{CDCl}_{3}\right): \delta=1.44(\mathrm{t}, 3 \mathrm{H}, J=7.0 \mathrm{~Hz}), 1.58(\mathrm{~d}, 3 \mathrm{H}, J=$ $7.2 \mathrm{~Hz}), 3.82(\mathrm{~s}, 3 \mathrm{H}), 3.85(\mathrm{~s}, 3 \mathrm{H}), 3.97(\mathrm{q}, 1 \mathrm{H}, J=7.2 \mathrm{~Hz}), 4.06(\mathrm{q}$, $2 \mathrm{H}, J=7.0 \mathrm{~Hz}), 6.56(\mathrm{~d}, 1 \mathrm{H}, J=2.2 \mathrm{~Hz}), 6.59(\mathrm{ddd}, 1 \mathrm{H}, J=0.5 \mathrm{~Hz}, J=$ $2.2 \mathrm{~Hz}, J=8.2 \mathrm{~Hz}), 6.72(\mathrm{~d}, 1 \mathrm{H}, J=8.2 \mathrm{~Hz}), 6.76(\mathrm{~s}, 1 \mathrm{H}), 6.79(\mathrm{~d}, 1 \mathrm{H}$, $J=1.7 \mathrm{~Hz}), 6.81(\mathrm{dd}, 1 \mathrm{H}, J=0.6 \mathrm{~Hz}, J=8.1 \mathrm{~Hz}) ;{ }^{13} \mathrm{C}$ NMR $(75 \mathrm{MHz}$, $\left.\mathrm{CDCl}_{3}\right): \delta=14.8,22.2,43.6,55.5,56.0,64.3,110.2,111.3,112.8$ $114.5,117.2,119.3,135.8,139.5,145.7,147.3,147.5,148.0$; MS (APCI) $[\mathrm{M+H}]^{+}=302$; Anal. calcd for $\mathrm{C}_{18} \mathrm{H}_{23} \mathrm{NO}_{3}$ : C 71.73, N 4.65, H 7.69, found: C 71.58, N 4.39, H 7.49.

\section{5-[1-(3,5-Dimethoxyphenyl)ethyl]-2-methoxyphenol} (23): $(251 \mathrm{mg}, 87 \%) ; R_{\mathrm{f}}=0.5\left(\mathrm{CH}_{2} \mathrm{Cl}_{2}\right) ;{ }^{1} \mathrm{H}$ NMR $\left(300 \mathrm{MHz}, \mathrm{CDCl}_{3}\right): \delta=1.62$ $(\mathrm{d}, 3 \mathrm{H}, J=7.2 \mathrm{~Hz}), 3.86-3.70(\mathrm{~m}, 6 \mathrm{H}), 3.89(\mathrm{~s}, 3 \mathrm{H}), 4.03(\mathrm{q}, 1 \mathrm{H}, J=$ $7.2 \mathrm{~Hz}), 5.64(\mathrm{~s}, 1 \mathrm{H}), 6.34(\mathrm{t}, 1 \mathrm{H}, J=2.2 \mathrm{~Hz}), 6.43(\mathrm{~d}, 2 \mathrm{H}, J=2.2 \mathrm{~Hz})$, $6.76(\mathrm{dd}, 1 \mathrm{H}, J=8.3, J=2.0 \mathrm{~Hz}), 6.81(\mathrm{~d}, 1 \mathrm{H}, J=8.3 \mathrm{~Hz}), 6.87(\mathrm{~d}, 1 \mathrm{H}$ $J=1.9 \mathrm{~Hz}) ;{ }^{13} \mathrm{C} \mathrm{NMR}\left(75 \mathrm{MHz}, \mathrm{CDCl}_{3}\right): \delta=21.8,44.4,55.3$ (2), 56.0, 97.6, $106.1(2), 110.5,113.9,118.9,139.5,144.9,145.4,149.1,160.7$ (2); MS (APCI) $[\mathrm{M}+\mathrm{H}]^{+}=289$; Anal. calcd for $\mathrm{C}_{17} \mathrm{H}_{20} \mathrm{O}_{4}$ : C 70.81, H 6.99, found: C 70.74, H 6.96 .
5-[1-(2,3-Dimethoxyphenyl)ethyl]-2-methoxyphenol

(24): $(233 \mathrm{mg}, 81 \%) ; R_{\mathrm{f}}=0.49\left(\mathrm{CH}_{2} \mathrm{Cl}_{2}\right) ;{ }^{1} \mathrm{H}$ NMR $\left(300 \mathrm{MHz}, \mathrm{CDCl}_{3}\right): \delta=$ $1.51(\mathrm{~d}, 3 \mathrm{H}, J=7.1 \mathrm{~Hz}), 3.65(\mathrm{~s}, 3 \mathrm{H}), 3.81(\mathrm{~s}, 6 \mathrm{H}), 4.48(\mathrm{q}, 1 \mathrm{H}, J=$ $7.2 \mathrm{~Hz}), \quad 6.71-6.82(\mathrm{~m}, 5 \mathrm{H}), 6.97 \quad(\mathrm{t}, \quad 1 \mathrm{H}, \quad J=8.0 \mathrm{~Hz}) ;{ }^{13} \mathrm{C} N M R$ $\left(75 \mathrm{MHz}, \mathrm{CDCl}_{3}\right): \delta=21.7,37.0,55.7,56.0,60.6,110.2,110.4,114.0$ 119.0, 119.8, 123.8, 140.0, 140.5, 144.7, 145.3, 146.5, 152.7; Anal. calcd for $\mathrm{C}_{17} \mathrm{H}_{20} \mathrm{O}_{4}$ : C 70.81, H 6.99, found: C 70.58, H 6.94.

5-[1-(3-Ethoxy-4-methoxyphenyl)ethyl]-2-methoxyphenol (25): (214 mg, $71 \%) ; R_{\mathrm{f}}=0.5\left(\mathrm{CH}_{2} \mathrm{Cl}_{2}\right) ;{ }^{1} \mathrm{H}$ NMR $\left(300 \mathrm{MHz}, \mathrm{CDCl}_{3}\right): \delta=1.33$ $(\mathrm{t}, 3 \mathrm{H}, J=7.0 \mathrm{~Hz}), 1.48(\mathrm{~d}, 3 \mathrm{H}, J=7.2 \mathrm{~Hz}), 3.74(\mathrm{~s}, 6 \mathrm{H}), 3.92(\mathrm{~m}, 3 \mathrm{H})$, $5.58(\mathrm{~s}, 1 \mathrm{H}), 6.59(\mathrm{dd}, 1 \mathrm{H}, J=8.3,2.1 \mathrm{~Hz}), 6.60-6.71(\mathrm{~m}, 5 \mathrm{H})$; ${ }^{13} \mathrm{C} \mathrm{NMR}\left(75 \mathrm{MHz}_{1} \mathrm{CDCl}_{3}\right): \delta=14.8,22.1,43.7,55.9$ (2), 64.2, 110.5, $111.3,112.6,113.85,118.74,119.24,139.16,140.16,144.78,145.38$, 147.54, 148.06, 153.62; MS (APCl) $[M+H]^{+}=303$; Anal. calcd for $\mathrm{C}_{18} \mathrm{H}_{22} \mathrm{O}_{4}$ : C 71.50, H 7.33, found: C 71.22, H 7.06.

2-Methoxy-5-[1-(2,3,4-trimethoxyphenyl)ethyl]phenol

(26): $(267 \mathrm{mg}, \quad 84 \%) ; \quad R_{\mathrm{f}}=0.2 \quad$ (cyclohexane/EtOAc 9:1); ${ }^{1} \mathrm{H}$ NMR $\left(300 \mathrm{MHz}, \mathrm{CDCl}_{3}\right): \delta=1.48(\mathrm{~d}, 3 \mathrm{H}, J=7.2 \mathrm{~Hz}), 3.59(\mathrm{~s}, 3 \mathrm{H}), 3.70(\mathrm{~s}$, $3 \mathrm{H}), 3.75(\mathrm{~s}, 3 \mathrm{H}), 3.77(\mathrm{~s}, 3 \mathrm{H}), 4.25(\mathrm{q}, 1 \mathrm{H}, J=7.2 \mathrm{~Hz}), 6.50-6.60(\mathrm{~m}$, $2 \mathrm{H}), 6.60-6.65(\mathrm{~d}, 1 \mathrm{H}, J=8.3 \mathrm{~Hz}), 6.70(\mathrm{~d}, 1 \mathrm{H}, J=1.9 \mathrm{~Hz}), 6.79(\mathrm{~d}$, $1 \mathrm{H}, J=8.6 \mathrm{~Hz}) ;{ }^{13} \mathrm{C}$ NMR $\left(75 \mathrm{MHz}, \mathrm{CDCl}_{3}\right): \delta=21.8,37.0,55.8,55.9$, 60.6, 60.8, 107.1, 110.4, 114.2, 118.2, 121.7, 132.7, 140.4, 142.2, 144.9, 146.1, 151.4, 151.9; MS (ESI) $[M-\mathrm{H}]^{-}=317$; Anal. calcd for $\mathrm{C}_{18} \mathrm{H}_{22} \mathrm{O}_{5}: \mathrm{C} 67.91, \mathrm{H} 6.97$, found: C 67.87, H 6.89.

3-(3-Hydroxy-4-methoxyphenyl)-3-(3,4,5-trimethoxyphenyl)propanenitrile (27): $(121 \mathrm{mg}, 50 \%) ; R_{\mathrm{f}}=0.4$ (cyclohexane/EtOAc 5:5); ${ }^{1} \mathrm{H}$ NMR $\left(300 \mathrm{MHz}, \mathrm{CDCl}_{3}\right): \delta=2.97(\mathrm{~d}, 2 \mathrm{H}, J=7.5 \mathrm{~Hz}), 3.83(\mathrm{~s}, 9 \mathrm{H})$, $3.88(\mathrm{~s}, 3 \mathrm{H}), 4.21(\mathrm{t}, 1 \mathrm{H}, J=7.6 \mathrm{~Hz}), 5.61(\mathrm{~s}, 1 \mathrm{H}), 6.42(\mathrm{~s}, 2 \mathrm{H}), 6.73-$ $6.83(\mathrm{~m}, 3 \mathrm{H}) ;{ }^{13} \mathrm{C}$ NMR $\left(75 \mathrm{MHz}, \mathrm{CDCl}_{3}\right): \delta=24.4,46.8,55.9,56.1$ (2), 60.8, $104.6(2), 110.7,113.6,118.5,118.9,134.3,137.1,137.2$ 145.8 (2), 153.4 (2); MS (ESI) $[M+N a]^{+}=366$; Anal. calcd for $\mathrm{C}_{19} \mathrm{H}_{21} \mathrm{NO}_{5}$ : C 66.46, N 4.08, H 6.16, found: C 66.39, N 3.99, H 6.09.

5-[2,2-Difluoro-1-(3,4,5-trimethoxyphenyl)ethyl]-2-methoxyphenol (28): $(220 \mathrm{mg}, 62 \%) ; R_{\mathrm{f}}=0.25$ (cyclohexane/EtOAc 7:3); ${ }^{1} \mathrm{H}$ NMR $\left(300 \mathrm{MHz} \mathrm{CDCl}_{3}\right): \delta=3.76(\mathrm{~s}, 9 \mathrm{H}), 3.83(\mathrm{~s}, 3 \mathrm{H}), 4.15(\mathrm{td}, 1 \mathrm{H}, J=$ $15.8 \mathrm{~Hz}, J=4.2 \mathrm{~Hz}), 5.51(\mathrm{~s}, 1 \mathrm{H}), 6.15(\mathrm{td}, 1 \mathrm{H}, J=55.9 \mathrm{~Hz}, J=4.2 \mathrm{~Hz})$, $6.42(\mathrm{~s}, 2 \mathrm{H}), 6.70-6.83(\mathrm{~m}, 3 \mathrm{H}) ;{ }^{13} \mathrm{C}$ NMR $\left(100 \mathrm{MHz}, \mathrm{CDCl}_{3}\right): \delta=54.5$ $(\mathrm{t}, J=20.7 \mathrm{~Hz}), 55.9,56.1$ (2), 60.8, 106.1 (2), 110.6, 115.1, 120.5, $116.8(\mathrm{t}, J=244.5), 130.0,132.7,137.3,145.6,145.9,153.2(2)$; ${ }^{19} \mathrm{~F}$ NMR: (188 MHz, $\mathrm{CDCl}_{3}$ decoupled): $-116.09,-116.12$; Anal. calcd for $\mathrm{C}_{18} \mathrm{H}_{20} \mathrm{~F}_{2} \mathrm{O}_{5}$ : C 61.01, H 5.69, found: C 60.81, H 5.46.

Synthesis of erianin: Erianin was prepared from the $\mathrm{Pd} / \mathrm{C}$ $(5 \mathrm{~mol} \%)$ catalytic reduction of $\mathrm{CA}-4^{[26]}$ in $\mathrm{MeOH}$ for $3 \mathrm{~h}$ at room temperature.

5-(3,4,5-Trimethoxyphenethyl)-2-methoxyphenol (erianin): (223 mg, 70\%); $R_{\mathrm{f}}=0.35 \quad$ (cyclohexane/EtOAc 8:2); ${ }^{1} \mathrm{H}$ NMR $\left(300 \mathrm{MHz}, \mathrm{CDCl}_{3}\right): \delta=2.82(\mathrm{~s}, 4 \mathrm{H}), 3.83(\mathrm{~s}, 9 \mathrm{H}), 3.86(\mathrm{~s}, 3 \mathrm{H}), 5.64(\mathrm{~s}$, $1 \mathrm{H}), 6.38(\mathrm{~s}, 2 \mathrm{H}), 6.64(\mathrm{dd}, 1 \mathrm{H}, J=2.1 \mathrm{~Hz}, J=8.2 \mathrm{~Hz}), 6.77(\mathrm{~d}, 1 \mathrm{H}$, $J=8.2 \mathrm{~Hz}), 6.81(\mathrm{~d}, 1 \mathrm{H}, J=2.0 \mathrm{~Hz}) ;{ }^{13} \mathrm{C}$ NMR $\left(75 \mathrm{MHz}, \mathrm{CDCl}_{3}\right): \delta=$ $37.3,38.4,56.0$ (3C) $60.9,105.4$ (2C), 110.6, 114.7, 119.8, 135.0, 136.1, 137.6, 144.9, 145.5, 153.0 (2C); MS (ESI) $[M+N a]^{+}=341$; Anal. calcd for $\mathrm{C}_{18} \mathrm{H}_{22} \mathrm{O}_{5}$ : C 67.91, $\mathrm{H}$ 6.97, found: $\mathrm{C} 67.87, \mathrm{H} 6.94$.

\section{Biology \\ Cell culture and proliferation assay}

Cancer cell lines were obtained from the American Type Culture Collection (ATCC; Rockville, MD, USA) and were cultured according to the supplier's instructions. Briefly, MDA-MB231, MDA-MB435, 
and H1299 cells were grown in Dulbecco's minimal essential medium (DMEM) containing $4.5 \mathrm{gL}^{-1}$ glucose supplemented with $10 \%$ fetal calf serum (FCS) and $1 \%$ glutamine. Human K562 leukemia and HCT-116 colorectal carcinoma cells were grown in RPMI 1640 containing $10 \%$ FCS and $1 \%$ glutamine. Human umbilical vein endothelial cells (HUVECs) were obtained from Clonetics (Lonza; Walkersville, MD, USA) and cultured according to the supplier's instructions. Briefly, HUVECs from three to six passages were subcultured to confluence onto $0.2 \%$ gelatin-coated tissue culture flasks in endothelial cell growth medium (EGM2) containing growth factors and $2 \% \mathrm{FCS}$. All cell lines were maintained at $37^{\circ} \mathrm{C}$ in a humidified atmosphere containing $5 \% \mathrm{CO}_{2}$. Cell viability was assessed using Promega CellTiter-Blue ${ }^{\mathrm{TM}}$ reagent according to the manufacturer's instructions. Cells were seeded in 96-well plates $(5 \times 103$ cells per well) containing $50 \mu \mathrm{L}$ growth medium. After $24 \mathrm{~h}$ culture, the cells were supplemented with $50 \mu \mathrm{L}$ test compound dissolved in DMSO $(<0.1 \%$ in each preparation). After incubation for $72 \mathrm{~h}, 20 \mu \mathrm{L}$ resazurin was added for $2 \mathrm{~h}$ before recording fluorescence $\left(\lambda_{\mathrm{ex}}=560 \mathrm{~nm}, \lambda_{\mathrm{em}}=590 \mathrm{~nm}\right)$ using a Victor microtiter plate fluorimeter (PerkinElmer, USA). IC $\mathrm{C}_{50}$ values correspond to the concentration of test compound that elicited a $50 \%$ decrease in fluorescence for drug-treated cells relative to untreated cells. Experiments were performed in triplicate.

Microtubule assembly assay: Sheep brain tubulin was purified according to the method of Shelanski et al. ${ }^{[27]}$ by two cycles of assembly-disassembly and then dissolved in the assembly buffer containing $0.1 \mathrm{M}$ MES, $0.5 \mathrm{~mm} \mathrm{MgCl}, 1 \mathrm{~mm}$ EGTA, and $1 \mathrm{~mm}$ GTP, $\mathrm{pH} 6.6$ (the concentration of tubulin was $\sim 2-3 \mathrm{mg} \mathrm{mL}^{-1}$ ). Tubulin assembly was monitored and recorded continuously by turbidimetry at $\lambda=350 \mathrm{~nm}$ in a UV spectrophotometer equipped with a thermostatic cell at $37^{\circ} \mathrm{C}$. All samples were dissolved in DMSO. The evaluated compound $(1 \mu \mathrm{L})$ was added to a microtubule solution $(150 \mu \mathrm{L})$ that was incubated at $37^{\circ} \mathrm{C}$ for $10 \mathrm{~min}$ and at $0^{\circ} \mathrm{C}$ for $5 \mathrm{~min}$ before evaluation of the tubulin assembly rate. The $\mathrm{Cl}_{50}$ value of each compound was determined as the concentration that decreased the maximum assembly rate of tubulin by $50 \%$ relative to the rate in the absence of compound. The $\mathrm{Cl}_{50}$ values for all compounds were compared with those of CA-4, colchicine, and phenstatin, and measured the same day under the same conditions.

Cell-cycle analysis: Exponentially growing cancer cells (K562, $\mathrm{H} 1299)$ were incubated with test compound or DMSO for $24 \mathrm{~h}$. Cell-cycle profiles were determined by flow cytometry on a FC500 flow cytometer (Beckman-Coulter, France) as described previously. ${ }^{[28]}$

Apoptosis assay: Apoptosis was measured by the Apo-one homogeneous caspase $3 / 7$ assay (Promega, WI, USA) according to the manufacturer's recommendations. Briefly, cells were subcultured on a 96-well plate with $5 \times 10^{4}$ cells per well in $100 \mu \mathrm{L}$ medium. After incubation for $24 \mathrm{~h}$, the medium in the 96-well plate was discarded and replaced with medium containing various concentrations of isoerianin derivatives $(5,10,50$, or $100 \mathrm{~nm})$. The treated cells were incubated for $24 \mathrm{~h}$, each well then received $100 \mu \mathrm{L}$ of a mixture of caspase substrate and Apo-one caspase 3/7 buffer. After incubation for $1 \mathrm{~h}$, the sample fluorescence was measured using a Victor microtiter plate fluorimeter (PerkinElmer, USA) at $\lambda=527 \mathrm{~nm}$.

Cord disruption assay: HUVECs $\left(2 \times 10^{4}\right.$ cells per well) were plated in 96-well plates on a thick layer of Matrigel (Becton Dickinson; $10 \mathrm{mg} \mathrm{mL}^{-1}, 60 \mu \mathrm{L}$ per well) and allowed to align for $24 \mathrm{~h}$. Isoerianin $3 \mathrm{a}$ or vehicle were added to the formed cords and left for $3 \mathrm{~h}$. Images were taken $3 \mathrm{~h}$ after the addition of compounds.

\section{Molecular modeling}

To verify the superimposition of isoerianin over the previously published isoCA-4 and colchicine, we performed docking studies over the tubulin active site. The X-ray structure of the tubulin-colchicine complex (PDB ID: 1SA0) was used for this study. Hydrogen atoms were added, and an energy minimization using AMBER $8.0^{[29]}$ was performed, keeping the $\alpha$-carbon atoms constrained by a constraint force of $50 \mathrm{kcal} \mathrm{mol}^{-1} \AA^{2}$, which permitted free movement of side chains while maintaining the same secondary structures. Over the refined model we defined the active site of tubulin as $12 \AA$ around the crystallized colchicine molecule. We performed a docking of isoerianin using the program GOLD 4.1.2. ${ }^{[30]}$ The X-ray structure of isoerianin was used for docking.

\section{Acknowledgements}

We thank the ICSN and the CNRS for their contribution and financial support of this research (doctoral fellowship to B.T.).

Keywords: antitumor agents $\cdot$ combretastatins $\cdot$ erianin isoerianin · tubulin

[1] G. R. Pettit, S. B. Singh, E. Hamel, C. M. Lin, D. S. Alberts, D. Garcia-Kendall, Experientia 1989, 45, 209-211.

[2] G. R. Pettit, M. R. Rhodes, D. L. Herald, E. Hamel, J. M. Schmidt, R. K. Pettit, J. Med. Chem. 2005, 48, 4087-4099.

[3] K. Ohsumi, R. Nakagawa, Y. Fukuda, T. Hatanaka, Y. Morinaga, Y. Nihei, K. Ohishi, Y. Suga, Y. Akiyama, T. Tsuji, J. Med. Chem. 1998, 41, 3022-3032.

[4] N. E. Mealy, B. Lupone, M. Balcell, Drugs Future 2006, 31, 547-548.

[5] D. M. Patterson, G. J. S. Rustin, Drugs Future 2007, 32, 1025-1032.

[6] D. W. Siemann, D. J. Chaplin, P. A. Walicke, Expert Opin. Invest. Drugs 2009, 18, 189-197.

[7] D. M. Patterson, G. J. S. Rustin, Clin. Oncol. 2007, 19, 443-456.

[8] G. R. Pettit, M. R. Rhodes, D. L. Herald, D. J. Chaplin, M. R. L. Stratford, E. Hamel, R. K. Pettit, J.-C. Chapuis, D. Oliva, Anti-Cancer Drug Des. 1998, 13, $981-993$.

[9] O. Provot, A. Giraud, J.-F. Peyrat, M. Alami, J.-D. Brion, Tetrahedron Lett 2005, 46, 8547-8550.

[10] C. Mousset, A. Giraud, O. Provot, A. Hamze, J. Bignon, J.-M. Liu, S. Thoret, J. Dubois, J.-D. Brion, M. Alami, Bioorg. Med. Chem. Lett. 2008, $18,3266-3271$.

[11] A. Hamze, A. Giraud, S. Messaoudi, O. Provot, J.-F. Peyrat, J. Bignon, J.M. Liu, J. Wdzieczak-Bakala, S. Thoret, J. Dubois, J.-D. Brion, M. Alami, ChemMedChem 2009, 4, 1912-1924.

[12] S. Messaoudi, B. Tréguier, A. Hamze, O. Provot, J.-F. Peyrat, J. Rodrigo De Losada, J.-M. Liu, J. Bignon, J. Wdzieczak-Bakala, S. Thoret, J. Dubois, J.D. Brion, M. Alami, J. Med. Chem. 2009, 52, 4538-4542.

[13] A. Hamze, D. Veau, O. Provot, J.-D. Brion, M. Alami, J. Org. Chem. 2009, $74,1337-1340$

[14] B. Tréguier, A. Hamze, O. Provot, J.-D. Brion, M. Alami, Tetrahedron Lett. 2009, 50, 6549-6552.

[15] Y.-Q. Gong, Y. Fan, D.-Z. Wu, H. Yang, Z.-B. Hu, Z.-T. Wang, Eur. J. Cancer 2004, 40, 1554-1565.

[16] a) M. A. Jordan, D. Thrower, L. Wilson, J. Cell. Sci.1992, 102, 401-416; b) M. J. Schilstra, S. R. Martin, P. M. Bayleys, J. Biol. Chem. 1989, 264, $8827-8834$.

[17] J. Barluenga, P. Moriel, C. Valdés, F. Aznar, Angew. Chem. 2007, 119, 5683-5686; Angew. Chem. Int. Ed. 2007, 46, 5587-5590.

[18] G. R. Pettit, B. Toki, D. L. Herald, P. Verdier-Pinard, M. R. Boyd, E. Hamel, R. K. Pettit, J. Med. Chem. 1998, 41, 1688-1695.

[19] F. Zavala, D. Guénard, J.-P. Robin, E. J. Brown, J. Med. Chem. 1980, 23, $546-549$.

[20] K. M. Boatright, G. S. Salvesen, S. Guy, Curr. Opin. Cell Biol. 2003, 15, $725-731$. 
[21] a) M. P. Chang, J. Bramhall, S. Graves, B. Bonavida, B. J. Wisnieski, J. Biol. Chem. 1989, 264, 15261-15267; b) A. McGahon, R. Bissonnette, M Schmitt, K. M. Cotter, D. R. Green, T. G. Cotter, Blood 1994, 83, 1179 1187; c) A. J. McGahon, W. K. Nishioka, S. J. Martin, A. Mahboubi, T. G. Cotter, D. R. Green, J. Biol. Chem. 1995, 270, 22625-22631; d) R. M. Gangemi, M. Tiso, C. Marchetti, A. B. Severi, M. Fabbi, Cancer Chemother. Pharmacol. 1995, 36, 385-392; e) L. Dubrez, F. Goldwasser, P. Genne, Y. Pommier, E. Solary, Leukemia 1995, 9, 1013-1024; f) S. Ray, G. Bullock, G. Nunez, C. Tang, A. M. Ibrado, Y. Huang, K. Bhalla, Cell Growth Differ. 1996, 7, 1617-1623.

[22] K. A. Hotchkiss, A. W. Ashton, R. Mahmood, R. G. Russel, J. A. Sparano, E. L. Schwartz, Mol. Cancer Ther. 2002, 1, 1191-1200.

[23] R. B. Ravelli, B. Gigant, P. A. Curmi, I. Jourdain, S. Lachkar, A. Sobel, M. Knossow, Nature 2004, 427-432, 198-202.

[24] T. L. Nguyen, C. McGrath, A. R. Hermone, J. C. Burnett, D. W. Zaharevitz, B. W. Day, P. Wipf, E. Hamel, R. A. Gussio, J. Med. Chem. 2005, 48, $6107-$ 6116.

[25] M. Alami, S. Messaoudi, A. Hamze, O. Provot, J.-D. Brion, J.-M. Liu, J. Bignon, J. Bakala, WO 2009/147217A1, PCT/EP2009/056885.
[26] A. Giraud, O. Provot, A. Hamze, J.-D. Brion, M. Alami, Tetrahedron Lett. 2008, 49, 1107-1110.

[27] M. L. Shelanski, F. Gaskin, C. R. Cantor, Proc. Natl. Acad. Sci. USA 1973 $70,765-768$

[28] C. Venot, M. Maratrat, C. Dureuil, E. Conseiller, L. Bracco, L. Debussche, EMBO J. 1998, 17, 4668-4679.

[29] D. A. Case, T. A. Darden, T. E. Cheatham III, C. L. Simmerling, J. Wang, R. E. Duke, R. Luo, K. M. Merz, B. Wang, D. A. Pearlman, M. Crowley, S. Brozell, V. Tsui, H. Gohlke, J. Mongan, V. Hornak, G. Cui, P. Beroza, C. Schafmeister, J. W. Caldwell, W. S. Ross, P. A. Kollman (2004), AMBER 8 University of California, San Francisco.

[30] M. L. Verdonk, J. C. Cole, M. J. Hartshorn, C. W. Murray, R. D. Taylor, Proteins Struct. Funct. Bioinf. 2003, 52, 609-623.

[31] N. L'Hermite, A. Giraud, O. Provot, J.-F. Peyrat, M. Alami, J.-D. Brion, Tetrahedron 2006, 62, $11994-12002$.

Received: October 22, 2010

Revised: December 14, 2010

Published online on $\square$ II, 0000 


\section{FULL PAPERS}

Breaking the cell cycle: We studied the anticancer activity of a series of new isoerianin derivatives bearing modifications at the $A$ and $B$ rings. Isoerianin was selected as a lead compound for its high antitumor activity.

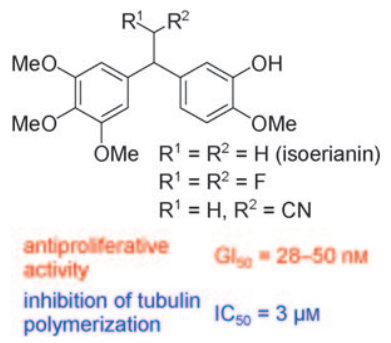

S. Messaoudi, A. Hamze, O. Provot,

B. Tréguier, J. Rodrigo De Losada,

J. Bignon, J.-M. Liu, J. Wdzieczak-Bakala,

S. Thoret, J. Dubois, J.-D. Brion, M. Alami*

$\mathbf{\square - a}$

Discovery of Isoerianin Analogues as Promising Anticancer Agents 